\title{
ETICA MEDICALĂ VERSUS MORALITATE POLITICĂ ÎN SECOLUL XXI
}

\section{Borcean Gheorghe ${ }^{1}$}

${ }^{1}$ medic primar chirurgie generală, specialist ortopedie și traumatologie, doctor în medicină, vicepreședinte Colegiul Medicilor din România

Acest material nu doreste să facă o revoluție în sistem; este dedicat colegilor cărora le sugerează o abordare logică și totodată inedită a unei probleme de zi cu zi, de care depinde existența lor. Este dedicat și oamenilor politici, celor care reglementează și administrează sistemul.

Autorul ține să facă legătura între evoluția istorică și întâmplările actuale, pentru a prezenta tuturor participanților la sistemul medical dificultățile existente, dar și pentru inițierea unei reforme durabile.

\section{Prefață}

Conform principiilor de bază ale practicii medicale stabilite încă de aproximativ doua mii cinci sute de ani în „Corpus Hippokratikum” și în „Jurământul lui Hippokrates”, datoria supremă a medicului este să mențină pacienții în viață și să le aline suferința, să nu le facă rău, să nu recurgă în cazul nimănui la mijloace letale - nici măcar când i se cere acest lucru - și, mai presus de toate, să treacă sub tăcere și să păstreze secret tot ce vede și ce aude în timpul, sau chiar în afara tratamentului și în relațiile sociale pe care acesta le are cu pacientul. Aceste principii se regăsesc și în Codul de Etică al medicilor români și în „Declarația de la Geneva” din 1948 a Asociației Medicale Mondiale varianta modernă a "Jurământului lui Hippokrates”. Din cauza relațiilor neobișnuite de încredere dintre pacient și medic, chiar și legislația română a hotărât că profesia de medic nu este o meserie; ea este prin natura sa o profesie liberală.

Aceasta implică fără îndoială, că toții medicii, prin natura practicării meseriei lor, se încadrează în categoria profesioniștilor liberali, așadar nu numai cei privați, independenți din punct de vedere economic, ci și cei care lucrează ca salariați. Cu acestă constatare, legiuitorul, în mod sigur nu a intenționat să le facă un serviciu medicilor, ci prin aceasta a conștientizat susținerea intereselor vitale ale pacienților în adevăratul sens al cuvântului.

Libertatea medicului este nevoia absolută de o decizie liberă a conștiinței, neinfluențată din exterior de alte domenii, ea este libertate în sensul libertății pentru pacienți și o dispoziție de apărare pentru pacienți.

Libertatea exercitării profesiei medicale va fi astfel esențial stabilită și limitată de nevoile de tratament ale fiecărui pacient în parte, de necesitățile, grijile, lipsurile și dorințele sale. În plus, condițiile exercitării profesiei medicale sunt reglementate prin hotărâri legale. Intervenția în cazul altei persoane se bazează pe dispozițiile din Codul Penal referitoare la leziunile corporale; intervenția este permisă numai după ce i s-a dat pacientului explicația corespunzătoare și după ce acesta și-a dat acordul. Răspunderea asumată pentru pacient este aşadar un criteriu inevitabil în cazul profesiilor liberale.

Prin nerecunoașterea sau suprimarea acestor principii de bază, legiuitorul a încercat, să reducă cheltuielile aflate în creștere din cauza unei pretinse „explozii a costurilor”. A fost trecut cu vederea faptul că totalitatea performanțelor în medicină nu au fost schimbate numai din punct de vedere cantitativ, ci au fost în special îmbunătăţite și modificate din punct de vedere calitativ, prin intermediul dezvoltării 
științei și tehnicii, prin extinderea serviciilor de salvare și a terapiei intensive. Aceasta a făcut posibilă prevenirea frecventă a decesului prematur, de multe ori cu prețul urmării unui tratament permanent.

De 30 de ani, speranța de viață în Romania a crescut cu 3 până la 4 ani pe deceniu. La o scădere simultană a natalității, va crește implicit numărul persoanelor de peste 60 de ani de la aproximativ 1/4 azi, la 1/3 din populație în anul 2040. Coeficientul de îmbătrânire, care indică relația dintre persoanele mai în vârstă și populația cu o vârstă aptă de muncă, se va dubla de la $35 \%$, la aproximativ $71 \%$.

Pronosticul unei pretinse explozii a costurilor, constant repetat încă de pe la sfârșitul anilor '90, care ar fi trebuit să ducă până în anul 2007 la scurgerea întregului Produs Intern Brut în sistemul de sănătate publică, s-a dovedit de mult a fi fals, ca multe altele. De fapt, partea cheltuielilor pentru asigurările medicale obligatorii din Produsul Intern Brut a crescut de la doar 3\% în anul 2000, la puțin peste 4\% în anul 2008.

Chiar și argumentul clasic întotdeauna folosit de politică, conform căruia cheltuielile salariale pentru menținerea capacității de competiție a economiei românești, trebuie să scadă prin limitarea contribuției asigurărilor medicale, s-a dovedit a fi o himeră. Peste jumătate din costurile salariale sunt costuri stabilite complet voluntar și de comun acord de angajatori și sindicate, pe când costurile salariale obligatorii reprezintă mai puțin de 50\%. În ceea ce privește costurile totale de muncă, partea angajatorului din asigurările medicale obligatorii se ridică la numai 5,5\%.

Politica ține în continuare sub tăcere faptul că până în urmă cu câțiva ani prin măsuri legislative asupra bugetului, s-au retras din sistem sume apreciabile de bani, care la vremea respectivă au constituit doar argumente politice în lupta electorală.

Afirmația invocată constant în mediul politic, precum că practicarea profesiei de medic în regim de profesie liberală și-a pierdut din atractivitate, deoarece se preferă desfășurarea activității în cadrul unui raport de angajare, poate fi de asemenea contestată cu ajutorul cifrelor.

Încrederea ridicată a populației din Romania în eficiența corpului profesional, marea apreciere a alegerii libere a medicului de către pacient și un raport esențial de încredere între pacient și medic, pentru un tratament eficient, dovedesc în mod evident faptul că idependența profesională deranjează și este un factor perturbator. Din această cauză și nu numai, se încearcă probabil, în discuțiile publice, crearea unei atmosfere nu neapărat favorabile, prin intermediul unor discuții neprincipiale și promovarea unei atitudini de neîncredere și chiar de ostilitate.

Chiar și firava autonomie experimentată inițial în cadrul legii asigurarilor de sănătate prin contractarea directă între Casa de asigurări și organizația autonomă profesională-Colegiul Medicilor din România, printre altele, pentru această funcție creat, a eșuat în scurtă vreme sub pretextul „profesionalizării”. Autonomia a trebuit sa fie transformată într-o autonomie controlată de stat.

Pentru sistemul de sănătate înțeles până acum ca social, au fost introduși în dezbaterea publică termenii de „economie medicală”, sau chiar „industrie medicală”. Pacientul a devenit beneficiar, iar medicul furnizor de servicii. În spital, activitățile medicale trebuie, în curând, organizate ca și în industrie. În acest fel, medicina devine medicină pe bandă rulantă. Pacientul nu mai este astfel tratat, ci prelucrat medical; el devine o entitate în lanțul creării de valori din industria medicală. La tratarea pacientului trebuie să fie luat în considerare și raportul dintre costuri și profit, ca și de exemplu în cazul reparării unui autoturism defect. În cazul unei disproporții între costurile „reparației” și durata de timp pentru care clientul beneficiază de această „reparație”, rămâne totuși o întrebare fără răspuns. Oricum, în nici un caz, scopul unei politici medicale raționale nu poate fi promovarea conceptului de „deces prematur tolerat de societate”.

Medicilor dirijați le corespund pacienții dirijați. În interesul libertății de decizie, a individualității fiecărei persoane și a nevoilor foarte diferite ale pacienților, luând în considerare boala, suferința și decesul, trebuie ca, în sfârșit, toate forțele reunite ale pluralismului și ale opțiunilor fiecărui individ, să acționeze în societatea noastră nu numai în vederea menținerii, ci și în vederea întăririi libertății profesionale și a profesiilor liberale. 
În mijlocul eforturilor trebuie să se afle întotdeauna individul; chiar prin adunarea unui număr mai mare de indivizi rezultă o majoritate, o diversitate, oricum niciodată o masă, un colectiv sau colectivism.

Scopul profesiei medicale și a asociațiilor din interiorul ei trebuie să fie reprezentat de lupta împotriva modernizărilor care doresc să combată boala prin stocarea tuturor datelor personale ale cetățenilor în computere și să contribuie astfel la însănătoșirea lor. Prejudiciile fizice și psihice rezultate dintr-o astfel de publicitate a tuturor aspectelor legate de intimitatea fizică și psihică, care nu pot fi descrise decât ca forme de lezare a individualității, sunt greu de imaginat.

Legiuitorul ar trebui, măcar de acum încolo, să se limiteze la stabilirea condițiilor generale, și nu să încerce să facă abuz de politica medicală ca politică de forță, pentru a promova aparențele care ne fac să credem că doar politica ar putea garanta siguranța și protecția individului.

\section{Sistemul de asigurări medicale obligatorii ca labirint al blocajelor}

Erich Weede, specialist în științe politice originar din Bonn, a caracterizat falimentul unei întreprinderi ca un mecanism de corectare a erorilor. Falimentul ar împiedica astfel continuarea producerii unor lucruri pe care de fapt nimeni nu le mai dorește. Din această perspectivă, sistemul asigurărilor medicale din România, în condiții de criză financiară continuă și presiune permanentă „pentru a aduce mai mulți bani în sistem”, apare ca o invitație deschisă la corectarea erorilor. Aceasta sugereaza falimentul, dar sistemul produce în continuare neobosit, pe alocuri chiar entuziast.

De ce se întâmplă acest lucru? Cei implicați sunt cu toții ghidați de mai multe decenii de indicații care sună promițător într-un presupus paradis medical pământean. Aceștia au promovat în mod continuu protecția socială sub toate formele ei. Acum, la final, lucrurile se află nu într-un context medical înfloritor, ci mai degrabă într-o mlaștină politică, pe drumuri birocratice încurcate și - mai cu seamă perfid - într-un labirint de blocaje alternative.

Sub pretextul că nimeni nu ar avea voie să se piardă, să fie dat la o parte sau uitat de-a lungul drumului, așa-zișii protectori sociali au reușit să impresioneze pe toată lumea, pentru a se apropia cât mai mult de public și de cei implicați. Dar această obligație social politică de a ademeni publicul, s-a transformat într-o harababură a constrângerilor. Prin urmare, în zilele noastre s-au încurcat toți reciproc și s-au împotmolit în sistemul de reguli de soluționare a reformelor.

Despre ce este vorba? Același cetățean matur, căruia, pe de-o parte, statul îi permite să își aleagă singur guvernul, nu este, pe de altă parte, la fel de stăpân pe propriul său corp. Sănătatea și îngrijirea sa sunt colectivizate și socializate prin obligația de asigurare. Felul, proporția și durata terapiilor sale sunt stabilite nu de cetățean, nici de medicul său, ci de comitete anonime - fãcând abstracție de cazuri concrete - de la distanță.

Pacientul nu are nici o altă opțiune, contribuția sa la Casa de asigurări sociale nu se materializează niciodată strict pentru persoana sa. În plus, patronii beneficiează de fructul vredniciei sau economiei lor și îi ghidează mai departe pe cetățeni spre autoritățile medicale competente. Medicii în contract cu Casele de asigurări, care doresc să iasă din tipar pentru a se ocupa cu medicina în loc să se ocupe de administrație, vor regresa până la prăbușirea lor individuală. Cel care reușește să mulțumească pacienții prin performanțele sale, răpește automat oferta de muncă a colegilor săi, sau a altor instituții de profil. Politica de intervenție macroeconomică în egalitatea globală dintre instituțiile sistemului medical se ghidează după dictonul „Divide et impera”.

Chiar și suveranii înșiși abia dacă mai sunt suverani; și ei sunt prinși, împiedicați, blocați în dezavantajul tuturor, de limitele și erorile labirintului de norme constant înnoite. Un partid împotriva altuia, un stat împotriva altuia, asociația împotriva statului, statul împotriva partidului, partidul împotriva administrației, administrația împotriva funcționarului, funcționarul împotriva sistemului, sistemul împotriva pacientului. Fiecare este împotriva fiecăruia, toți sunt împotriva tuturor. 
Despre ce era vorba la început? De acord, despre sănătate. Pentru toți. Noi am uitat complet de acest lucru; cine dorește să facă fericit colectivul prin organizare, acela le este cel mai puțin de folos săracilor. Acestă lecție de istorie a omenirii trebuie să fie acum învățată de asigurările medicale obligatorii.

\section{Drumul spre victimele bugetului}

\section{Istoric}

„Noi Wilhelm, din grația lui Dumnezeu, împărat al Germaniei și rege al Prusiei, decretăm în numele imperiului, prin consimțământul consiliului federal și al parlamentului, după cum urmează:(...)”

Așa începe prima parte a legii asigurărilor medicale din 15 iunie 1883, iar primul paragraf poartă frumos antetul: „A. Obligația de asigurare”. Atunci s-a născut Asigurarea Medicală Obligatorie, (GKV = Gesetzliche Krankenversicherung = Asigurarea Medicală Obligatorie), la care astăzi aproximativ 90\% din populația Germaniei sunt membri coercitivi. Inițial, în anul 1900, circa 40\% din populație erau membri coercitivi, această asigurare fiind gândită numai pentru „noua” pătură de atunci a muncitorimii industriale, care trebuia să fie asigurată împotriva bolilor care îi puteau periclita existența.

Bismarck, căruia i se atribuie paternitatea acestei legi, nu a făcut nici o referire la aceasta în lucrarea sa autobiografică „Gânduri și amintiri”, publicată în anul 1893. Poate că abia după 10 ani de la introducerea legii și-a dat seama de importanța acesteia. Referitor la această idee, nu este lipsită de picanterie părerea exprimată de Ernst Schweininger, medicul personal al lui Bismarck, în cartea sa „Der Arzt” („Medicul') publicată în 1906 (p. 108): "Tot aud aici cuvântul societate; cine este societatea aceasta? Pentru mine este o masă de indivizi adunați la un loc și, drept urmare, transformați, o mulțime in care individul se stinge, el dispare complet, nemaiputând fi regăsit. Pentru medic există doar indivizi, de fapt doar individul: pacientul, dar niciodată numărul mare de indivizi, care adunați la un loc să devină o altă ființă. Această ființă pentru mine ca medic este un nimeni! Nu îmi pasă deloc de ea..."

În 13 septembrie 1900 a fost deja fondată „Asociația Defensivă a Medicilor Germani pentru Apărarea Intereselor lor Profesionale”, pe scurt „Asociația din Leipzig”. S-au pus oare astfel în evidență posibilități de protecție? Prof. Bergdolt ${ }^{1}$ indică faptul că, prin legislația lui Bismarck, competiția medicală s-a obținut forțat: „Medicii au incercat cu disperare prin toate trucurile posibile să obțină o aprobare de limitare a costurilor din partea caselor de asigurări, pentru a se detașa reciproc, invingând adversarul." Iar Bergdolt îl citează pe August Bebel, președintele fracțiunilor parlamentare ale Partidului Social-Democrat, care în anul 1891 a lansat acuzația că medicii aflați în competiție pentru un contract cu casele de asigurări, sfidează competiția prin mijloace financiare, punându-și colegii într-o situație nedemnă. Bebel: „Drept urmare, avem cazuri aici în Berlin, în care se reține o indemnizație la o singură consultație a medicului, care chiar și pentru un muncitor necalificat este prea joasă. Ea se ridică adesea la o valoare foarte mică. "Atunci ca și acum, în Germania și în România, era interzisă prin codul deotologic concurența ilegală prin practicarea de tarife mai mici decât cele ale pieței.

În $1906 \mathrm{~s}$-a încheiat un contract colectiv pentru medicii de vas, în anul 1907 un contract colectiv cu Casele comerciale centralizate de asistență socială, iar în 1909 cu „Asociația Societăților Germane de Asigurare pe Viață”. În mod evident a fost nevoie de toate acestea, pentru că și medicul are nevoie de protecție, din moment ce numai el este cel care poate trata pacientul. Ei se completează unul pe celălalt: dacă medicul nu este protejat, bolnavul va avea de suferit.

În ciuda câtorva contracte și în ciuda unei mici părți de populație asigurată (în cazul condițiilor actuale), casele de asigurări sociale au ocupat o poziție extrem de influentă vis-a-vis de medici. Acestea au încheiat contracte individuale cu medicii ce depindeau de ele, putând astfel să pună condiții; participarea medicilor la stabilirea onorariului a trebuit stopată. Din comportamentul caselor de asigurări sociale a reieșit încă de la început că se urmărește „egalitatea” în interiorul corpului medical.

1 Prof. Dr. med. Dr. Phil. Klaus Bergdolt, Institutul pentru Istoria și Etica Medicinei, Köln: „Doctori și competiție, conferință de gală cu prilejul împlinirii a 60 de ani de la înfințtarea camerei federale a medicilor" 
În octombrie 1913 medicii au hotărât începerea grevei generale împotriva exercitării puterii unilaterale a caselor de asigurări, guvernul intervenind pentru înlăturarea acestei greve. Au fost stabilite primele dispoziții ale unei autonomii multiple. Casele de asigurări sociale au plătit diferențiat medicii, o parte prin rambursări globale și o parte prin rambursări în funcție de performanțele individuale. Întreaga dezbatere referitoare la factorii care motivează performanța medicală, la normele ce ar fi mai ușor de aplicat și la principiul care ar duce la extinderea, respectiv la reducerea performanței, a avut loc încă dinaintea primului război mondial.

În anul 1928 asociația de la Leipzig, căreia i s-a schimbat denumirea în „Asociația Harmann” după moartea lui Harmann, a impus Regulamentul General German pentru Stabilirea Taxelor. În 1932 a intrat în vigoare un contract cu cele mai importante case de asigurări sociale. Sub amprenta crizei economice mondiale și a decretelor speciale pentru situații critice ale lui Brüning, Asociația Harmann a devenit un partener public legal al caselor de asigurări sociale. Au fost înființate asociații regionale ale medicilor în contract cu casele de asigurări medicale, dar prin dispoziția din 2 august 1933, acestea au fost iarăși interzise de către naziști; în locul acestora a fost înființată o singură asociație a medicilor în contract cu casele de asigurări medicale, devenind extrem de rapid un instrument al statului. Această dispoziție a transformat autodeterminarea medicilor într-un organ executiv la nivel de stat, care reprezintă asociațiile medicilor în contract cu casele de asigurări și astăzi. Paragraful 1, aliniatul 3: „Asociația medicilor în contract cu casele de asigurări medicale din Germania este subordonată ministrului muncii, atâta timp cât nu există sau nu se justifică un alt for propriu de control.", există și astăzi reformulat. ${ }^{2}$

\section{Exploatarea moralității medicale}

Etica medicală nu este etică medicală ,în sine”. Ea rezultă din cererea de tratament a pacientului. Medicul care nu își respectă și nu își „iubește” pacienții, nu poate vindeca; pacientul care nu își respectă medicul, nu poate fi vindecat.

Aceste premise ale actului medical distrug politica în mod consecvent și sistematic. Politica nu are în vedere deloc oamenii bolnavi, ci doar menținerea influenței. Corpul medical a tratat întotdeauna pacienții luând în considerare principiile de etică, atât în spitale, cât și în cabinetele medicale. Reprezentanții politici au recunoscut într-adevăr cum își pot extinde și consolida dreptul la putere și care e modalitatea în care se conduce în ziua de astăzi: „prin îngrijire cu devotament”. Promisiunea de îngrijire cu devotament nu poate fi respectată, pentru că promite ceva ce trebuie respectat de ceilalți - o păcăleală clasică.

Bismarck dorea să se folosească de această „îngrijire” în rândul muncitorilor industriali fără școală, prin case de asigurări ale veniturilor, în caz de accident și prin casele de asigurări medicale, pentru a nu da apă la moară socialiștilor, în special a celor din Partidul Social-Democrat: chiar și aici este clar motivul menținerii puterii. Bismarck însă nu s-a gândit la îngrijirea întregii populații. Posibilitatea și necesitatea dobândirii și menținerii puterii, prin îngrijire, au fost făcute cunoscute, pentru prima dată, odată cu național-socialismul.

Din anii '70, paradigma politică a îngrijirii universale a fost sistematic transformată. Această paradigmă stă la baza clădirii puterii politice a partidelor populare. Astfel trăiesc și administrațiile exagerate. Interesul pentru putere domină între timp totul; este înființată o clasă politică, ce se agață de fiecare recompensă pentru menținerea sistemului.

2 Aici nu trebuie omisă o altă analogie cu situația actuală. Prin legea din 25 aprilie 1934 Hermann Goring, în calitate de prim-ministru al Prusiei și ministru al afacerilor interne, a dispus încredințarea competențelor Adunării Membrilor Camerei Stomatologilor, comitetului de conducere al camerei și o reorganizare a acestuia. În acest context a fost luată puterea comisiei democratice a Adunării Camerei Medicilor Stomatologi. În 1 aprilie 1934 funcția fostului comitet de conducere a camerei a fost declarată nulă. Noua adunare a fost numită de Göring. Legile de modernizare au prevăzut, în mod obligatoriu, din anul 2005, titulatura comitetelor de conducere a asociațiilor caselor de asigurări medicale, respectiv ale asociațiilor caselor de asigurări medicale ale stomatologilor. În caz de nerespectare a legii, ministrul sănătății numește un comisar în locul acestui comitet. Astfel, adunările reprezentanților corporațiilor au fost din nou private de putere. 
Aproape neobservaă a apărut o nouă categorie pentru menținerea sistemului: complexul medicalindustrial $^{3}$. Acesta a înlăturat mai multe componente, de exemplu sindicatele, din rolul decisiv, sau cel puțin asta urmează să facă. Sindicatelor le rămâne - mila nu își are locul - un colțișor comod în interiorul clasei de beneficiari birocratici. Complexului medical-industrial îi va reveni mai târziu mult mai mult.

\section{Dilema etică}

Pacientul, care atâta timp cât este sănătos nu este interesat de toate aceste evenimente, are numaidecât următoarea dilemă: așadar să credă în promisiunile politice care-i spun că primește o îngrijire medicală optimală? Poate el să creadă că medicul îl îngrijește bazându-se exclusiv pe cele mai bune cunoștințe, pe conștiință și „lege artis”? Medicul nu-i poate înlătura dilema: fie îi pune un diagnostic corect și îi prescrie terapia și medicația, cu riscul de a suferi pierderi economice, fie se adaptează la directivele politice și îngrijește pacientul făcând apel la medicina normată de către „comisii mixte” prin ghiduri, norme și protocoale, în speranța că pacientul nu observă.

Singurul procedeu care poate fi susținut de etică este lămurirea pacientului în legătură cu restricțiile cauzate de politică, punerea mai exactă a diagnosticului și indicarea unor mai bune posibilități de terapie sau medicație, pe care acesta trebuie să le plătească personal. Acest procedeu prezintă diferite rezerve: pe de o parte, datorită sincerității sale, medicul își poate determina pacientul să meargă la alt medic, pe de altă parte trebuie să ia în considerare restricțiile de la casele de asigurări medicale, care doresc să ascundă pacienților o explicație reală legată de fiecare preț.

Această dilemă etică este o piatră de temelie a principiilor politice. Casele de asigurări medicale pun medicii într-o „,competiție legată de etica profesională”. Aceasta este o competiție fără sprijin din partea caselor de asigurări. Medicii care iau parte la această competiție, se distrug singuri profesional. Medicii care nu iau parte și care le explică pacienților despre sfârșitul economic al sistemului de case de asigurări medicale, sunt defăimați. Dar atâta timp cât medicul își asumă aceste riscuri și nu îi dă pacientului explicațiile necesare, acesta va trece de partea adversarului. De îndată ce pacientul se consideră iarăși sănătos și nu mai vine la consultație la medic, așadar este „doar” un asigurat, trebuie să dea crezare promisiunilor politice și tuturor „reformelor” și să fie de părere că totul este în avantajul său. Acest asigurat încă mai crede că drepturile care i se cuvin îi sunt respectate, și anume dreptul la autodeterminare, dreptul la confidențialitatea datelor, dreptul la obligația medicului de a păstra secretul profesional. El nu își dă seama de faptul că realitatea este cu totul alta, iar medicul nu trebuie să îi spună acest lucru.

Un pacient care se duce fie la medicul de familie, fie la medicul specialist, la fel de încrezător ca și până acum, nu știe de regulă nimic despre faptul că nici diagnosticul, nici terapia nu sunt prescrise de „medicul său de la casa de asigurări”, ci de autorii unor ghiduri și acte normative. El nu știe că măsurile în ceea ce privește diagnosticul sunt supuse unor restricționări „statistice” și că cea care stabilește care medicament este cel mai bun pentru însănătoșirea sa este o „comisie” oarecare, străină de el și căreia nu i s-a adresat.

\section{Tehnocrația în farmacoterapie}

În România guvernele s-au simțit obligate să reglementeze furnizarea de medicamente pacienților. Este incert dacă se vor face de fapt economii, deoarece nu este realizat un bilanț general. Cu toate acestea, reglementările imorale sunt obținute prin constrângere, fiind bombardate de neologisme

3 A nu se confunda cu industria farmaceutică, care indică mai degrabă pierderea pe piața germană. Umbla vorba la nivel internațional, cum că piața medicală germană are un volum de 450 miliarde de euro. Fără a ști care sunt regulile de distribuție, este suficientă doar valoarea pentru fiecare "global player”, pentru a se interesa de această piață. „Global player” nu înseamnă implicit că acesta trebuie să vină de peste ocean. Avem chiar și în Germania parteneri absolut impunători: Bertelsmann, Siemens, SAP, Telekom, Deutsche Bank. Fiecare dintre aceștia trebuie să investigheze, în mod inevitabil, dacă un astfel de volum de finanțe oferă șanse economice și posibilități de dezvoltare. Unii dintre acești „global players” au o poziție atât de bună, încât pot influența politica națioală. 
pseudoștiințifice, false din punct de vedere profesional, sau lipsite de sens ca: „inovație aparentă”, „preparat analog”, sau „substanță activă” și multe altele.

$\mathrm{Cu}$ ajutorul instituțiilor de control conduse de stat, a institutelor pentru asigurarea calitătiii și împreună cu transformarea instanțelor, până acum independente științific, în agenții dependente, s-a pregătit terenul pentru abandonarea artei medicale a terapiei individuale.

$\mathrm{Nu}$ pacientul se află în centrul politicii, ci o reducere a costurilor, ca și în cazul contractelor de rabat. Pacientului i se raționalizează și prescrierile medicamentelor şi este tras pe sfoară în legătură cu situația reală și consecințele ei. Valorile medii justificate de instanțele pe probleme sociale sunt inadecvate valorii distribuite în mod normal. Pentru a putea justifica raționalizările, adică îngrădirea unei farmacoterapii individuale, principii importante ale statisticii și ale teoriei cunoașterii sunt ignorate, astfel fiind posibilă o standardizare a farmacoterapiei.

Medicii fie devin tot mai slab pregătiți, fie sunt restricționați în libertatea terapiei. Complexitatea unei terapii este negată. Medicii sunt constrânși să abuzeze de cunoștințele lor vis-a-vis de pacient. Consecința este pacientul ca victimă a bugetului și medicul cu sindromul burn-out, care se simte șantajat. Medicul este răsplătit pentru tratarea inadecvată a bolnavului.

Cinismul încercării de standardizare devine clar, medicii încolțiți fiind sfătuiți să nu își asume atât de mulți pacienți cu boli grave: „încercați să stați de-o parte!” Bugetului îi plac pacienții cu boli ușoare. Aceasta degradează medicul, transformându-l într-o sursă de bani pentru buget.

Heteronomia și caracterul mincinos sunt trăsăturile acestui sistem de prestare de asigurări. Pacientul nu este întrebat, în locul său hotărăsc casele de asigurări medicale, serviciile medicale, nenumăratele comisii și în final, politica. Aceștia le ordonă tot mai mult medicilor ce trebuie și ce nu trebuie să facă. Faptul că organizațiile de castă implementează aceste legi, arată decăderea valorilor independenței şi a moralităţii medicale.

\section{Evidence Based Medicine văzută ca abuz politic}

Un neologism cu semnificații aparente în interiorul activității medicale este Evidence Based Medicine. Termenul are semnificații pentru neprofesioniștii din medicină, pentru clasa politică, pentru complexul medical-industrial. ${ }^{4}$ Ea este o tehnică modernă, abuzată de guvernarea politică, folosită pentru a mușamaliza raționalizarea, pentru a-i pasa medicinei răspunderea pentru raționalizare.

Neprofesionistul care înțelege engleza, trebuie să se aștepte la mai multe de la cele trei cuvinte decât se ascunde în spatele lor. El trebuie să pornescă de la faptul că Evidence Based Medicine cuprinde un diagnostic și o terapie superioară, bazată pe „dovezi”. Minciuna politică funcționează și aici pe mai multe planuri.

Se pretinde că orice medicină care nu este bazată pe acele dovezi, este practicată în vidul științific, în aparență nemedical.

Se pretinde că medicii care nu practică medicina bazată pe dovezi, furnizează performanțe cu valori medicale discutabile, cauzând astfel costuri inutile.

Se pretinde că prin aplicarea consecventă a medicinei bazate pe dovezi, crește calitatea îngrijirii medicale, dar costurile scad.

Se pretinde că Evidence Based Medicine face posibilă o îngrijire medicală standardizată cu potențial de economie considerabil, iar medicii poartă vina pentru nevoia financiară, deoarece refuză aplicarea ei consecventă. Astfel, medicii intră în regres pe bună dreptate, practicând medicina „neștiințifică” și suportând și costurile.

Se pretinde că raționalizările comandate politic sunt utile din punct de vedere medical.

4 Prof. Mayer (Greifswald) în Major M. Ash, „Schienentherapie - Evidenzbasierte Diagnostik und Behandlung bei TMD und CMD”, Editura Urban\&Fischer, ediția a III-a, 2006: „practica bazată pe dovezi nu este o practică bazată pe dovezi ale cercetării; în plus, este vorba de o bine chibzuită întrebuințare a dovezilor științifice pe baza și experiența medicilor și a stomatologilor, corelate cu nevoile și preferințele pacientului. [...] Studii clinice randomizate controlate (SCR) aduc dovezi despre grupe, nu despre indivizi. Eficiența în SCR nu oferă garanție pentru eficiența în cazul comunitătiii. Eficiența în general nu este, la rândul său, o garanție pentru eficiența în cazul fiecărui pacient în parte.” 
Orice măsură medicală căreia nu i se aduc dovezi, este umbrită de o suspiciune generală a caracterului neștiințific.

\section{Pierderea autodeterminării}

Profesorul Karsten Vilmar fostul presedinte al Bundesartzekammer, consideră de-a dreptul înspăimântătoare imaginea complet mecanicistă a politicienilor și a economiștilor despre medicină, care cred cu tărie că sistemul de sănătate publică se poate redresa cu stabilirea „liniilor directoare științifice”, care trebuie mai apoi numai prelucrate intens, ca într-un atelier de reparații auto. Cum trebuie să se împace aceasta cu autonomia pacientului solicitată la fel de vehement, rămâne o enigmă.

Medicina constă în diagnostic și terapie, foarte mult în comunicare, în consultarea și sfătuirea pacientului. Timpul necesar acestor lucruri este considerabil redus prin pretenții birocratice pe de o parte și plată insuficientă pe de altă parte.

Adesea medicul nu își mai face timp pentru a-i explica pacientului restricțiile impuse de lege în ceea ce privește tratamentul său. El acceptă aceste restricții și pune pacientul său încrezător în fața faptului împlinit.

Mai rău este când medicul diagnostichează nesatisfăcător și propune o terapie împotriva convingerii și a unor mai bune cunoștințe ale sale, pentru că îi este frică să aleagă între medicina caselor de asigurări și medicina optimală. Acesta nu este cazul tipic, dar relația medic-pacient a fost deja otrăvită.

Dar chiar și medicul care lucrează ireproșabil din punct de vedere etic, explicându-i pacientului său de fiecare dată care sunt posibilitățile medicinei și scoțând în evidență limitele impuse de casele de asigurări, suferă datorită conflictelor irezolvabile ale sistemului. Activitățile sale ireproșabile din puncte de vedere etic nu sunt defăimate de sistem decât atunci când medicul nu aduce vorba despre acesta și când i se mușamalizează în continuare pacientului pierderea autodeterminării.

Un medic aflat sub tutela politică nu poate apăra drepturile pacienților. Birocrația cu siguranță nu poate face acest lucru. Autodeterminarea bolnavului este pusă în evidență de medicul independent. Cine îngenunchează medicul, îngenunchează și pacientul.

\section{Moral hazard - o păcăleală a colectivului}

Asiguratul din sistemul de prestări de asigurări devine inevitabil victimă a moral hazard-ului ${ }^{5}$. Termenul acesta de moral hazard este cunoscut încă din asigurările de drept privat. Cu cât circumstanțele de asigurare sunt mai neclare și mai necorespunzătoare, cu atât este mai mare ispita de a simula doar cazurile în care asigurarea garantează.

În sistemul asigurărilor medicale obligatorii, această cerință, moral hazard-ul, este cea mai mare. Asiguratul, care nu-și monitorizeaza casa de asigurări medicale, deoarece este sănătos sau deoarece îmbolnăvirea lui nu necesită tratament medical, se simte dezavantajat față de vecinul său care e și el asigurat și care la orice guturai merge la medic, i se prescrie o rețetă, este declarat ca inapt medical pentru muncă și timp de două zile nu apare la serviciu ${ }^{6}$. Consultarea medicului pentru acest fleac este în interesul asiguratului din două motive. În primul rând își exercită dreptul pentru care plătește contribuția lunară și care „i se cuvine”, iar în al doilea rând primește o consultație profesională, care altfel nu i-ar fi fost „acordată”.

5 WIKIPEDIA: Moral Hazard (engl., literalmente „risc moral”, denumit și ca risc subiectiv sau ispită morală) descrie pericolul unei schimbări de comportament după suprimarea aparentă a unui risc. Inițial era un termen din domeniul științei asigurărilor, iar astăzi e folosit adesea și în economie. Moral Hazard amenință când există o contradicție între ceea ce este rațional pentru comunitate (pentru colectiv) și ceea ce este rațional pentru individ, adică atunci când există o contradicție între raționalitatea colectivă și raționalitatea individuală. Astfel, Moral Hazard este în strânsă legătură cu cazurile de raționalitate. Un Moral Hazard amenință când o instanță mai înaltă, de exemplu un guvern, sau o instanță colectivă, de exemplu o asigurare, dorește impunerea unei raționalități colective. Dar aceasta este utilizată de indivizi, în favoarea intereselor lor personale, fiind astfel, pe cât se poate, subminată.

6 Pentru prescripția, în care medicul „scrie” că pacientul s-a îmbolnăvit și ca atare este inapt pentru muncă, pacientul este constrâns de situație să-l caute pe medic atunci când, după intuiția lui subiectivă, nu ar avea deloc nevoie de el. 
Politica a încercat, prin introducerea taxei pentru cabinetul medical în unele țări, să diminueaze numărul vizitelor la medic pentru astfel de motive. Dar după ceva timp acestă taxă a fost scoasă, întrucât efectul a fost invers. Asiguratul, pentru a folosi efectiv integral taxa sa pentru cabinetul medical, consultă în același trimestru diferiți alți medici specialiști tot pentru fleacuri, pentru care în mod normal nu s-ar fi dus neapărat la medic ${ }^{7}$. Asiguratul acționează eficient în ceea ce privește repartizarea „taxei” sale de cabinet medical.

Chiar și medicul ajunge în dilema moral hazard-ului. Pe de o parte, acestuia i-ar plăcea să sfătuiască pacientul cum să se ajute singur din punct de vedere medical, în cazul îmbolnăvirii ușoare, pe de altă parte se teme că pacientul ar putea merge la alt medic. De altfel, îi lipsesc cazurile ușoare pentru a-și valorifica rațional bugetul și pentru a nu intra în regres. Astfel, sistemul de prestare de asigurări are grijă să sancționeze comportamentul corect și să-l răsplătească pe cel fals.

\section{Birocrația terapeutică}

De mult suntem martori ai „birocrației terapeutice”, anunțată în anul 1792 în cadrul revoluției franceze. Ea a descoperit „a treia chestiune” dintre medic și pacient. În timp ce medicului i se supuneau țelurile „societății”, bolnavul trebuia să moară la o mărime statistică. ${ }^{8}$

Acțiunile socialiste ale secolului XX erau foarte îndepărtate în anul 1792, deși erau deja plănuite. Ele trebuiau să servească la fericirea socială. Nu oamenii simpli își doreau asta, ci intelectualii care erau conștienți de cât de elegant se poate conduce, când se promite „binele”. Apăruse interesul personal, alianța nelegiută a grupurilor de interese, care trăiau din această mizerie.

Cine îl făcea pe medic dependent de birocrație, subjuga și pacientul. Acest lucru este simplu: medicului i se taie pur și simplu o treime din onorariul său, datorită costurilor sale fixe ce constituie o mare parte a venitului său. Mai rău, el este astfel șantajat politic - în sensul aducerii unui prejudiciu pacientului său, „victimei bugetului”. Împreună cu birocrația tot mai avansată, istovirea medicului este inevitabilă.

Das Deutsche Ärzteblatt (Gazeta medicilor germani) scrie în 18 mai 2007 în chintesența metaanalizei diferitelor studii: „cu cât libertatea de acțiune ar rescricționa mai mult resursele sau cantitățile, cu atât ar rezulta mai devreme o corelație negativă cu satisfacția muncii”. Astfel, evident că este chinuitor pentru propriul psihic când trebuie să trimiți pacienții acasă fără să fie vindecați în totalitate, pentru că numai astfel spitalul poate supraviețui.

Așa procedează politica cu singurul capital real de care dispune sistemul de sănătate publică: profesioniștii liberali.

Acest lucru se întâmplă treptat, fără să fie conștientizat de medic. El se confruntă zilnic cu pacienții săi, care așteaptă să fie ajutați, fiind conștient de faptul că este constrâns să reprime ce a învățat odată. El este conștient că va fi pedepsit cu vârf și îndesat, dacă nu se conformează ordinelor "celei de-a treia chestiuni”.?

7 Chiar și prescripția, în care medicul de familie trebuie să facă trimitere asiguratului, pentru ca acesta să plătească taxa pentru cabinetul medical doar o singură dată, nu a avut efectul dorit. În schimb, asiguratul poate prezenta, în loc de singura trimitere necesară, simultan mai multe trimiteri ,în avans”.

8 Adunarea Națională de la Paris din anul 1792 a discutat luni în șir despre cum ar putea medicii să înlocuiască o birocrație terapeutică, astfel încât aceștia să scoată profit din îngrijirea bolnavilor.

9 Prof. Karsten Vilmar: „Cifrele bugetare influențează indicațiile pentru măsurile individuale de tratament și mai ales pricinuiesc selecția pacienților cu mai multe boli, dintr-o categorie de vârstă mai înaintată. Această selecție a riscului duce la punerea în aplicare a unor procedee de tratament avantajoase din punct de vedere al costurilor; pacienții al căror tratament este scump sau în cazul cărora pot apărea complicații, sunt în schimb, datorită repercursiunilor financiare, trimiși la alți medici sau la alte clinici - eventual sunt „expulzați”, dar și invers. Competiția economică impusă politic nu duce la reducerea cheltuielilor, ci provoacă pur și simplu mecanisme de învăluire, din cauza cărora are de suferit chiar îngrijirea persoanelor mai în vârstă, cu mai multe boli, cu riscuri adesea inimaginabile." (din cadrul unei conferințe din 19 mai 2005, „Ärztliches Handeln im Spannungsfeld zwischen Humanität und Kostendruck” - „Modul de acțiune in plan medical in zona tensionată dintre umanitate si presiunea costurilor") 


\section{Political hazard}

„Democratizarea medicinei” a fost un nou balon desenat în care erau vorbele clasei politice, care nu trebuia să se ocupe de pacienții majori, ci care trebuia să hrănească drepul de autoputernicie al statului. În spatele acestor vorbe se ascundea intenția politică de a distruge raportul de încredere dintre medic și pacient, dezvoltat de secole, notificat prin intermediul termenului de „semizeu în costum alb”. Acest lucru nu i-a reușit clasei politice nici până în ziua de azi.

Politica a trebuit să privească îmbolnăvirea oamenilor din propria perspectivă politică, însă nu există vindecare birocratică. Pacientul știe din instinct că vindecarea nu este posibilă fără încredere. Vindecarea și autovindecarea presupun un pacient cu autorăspundere și un medic independent, care nu trebuie dădăcit.

Libertatea și autorăspunderea dispar când puterea politică vrea să se amestece în zona vindecării. Dacă politica s-ar fi limitat la câmpul său de activitate - puterea de finanțare a propriului sistem de redistribuire a asigurărilor medicale obligatorii - ar fi eșuat minciuna aceea „de toate pentru toți”, iar imposibilitatea acestei îndrăzneli ar fi fost evidentă. Eroarea politică ar fi fost demascată, iar dreptul la putere ar fi fost pierdut. Pentru a se ocoli acest lucru, trebuie intervenit în câmpul politic al îmbolnăvirii și al tratamentului, care nu este deloc accesibil, așadar în raportul individual dintre medic și pacient.

Este evident că un politician sau un funcționar din minister nu înțelege nimic din tratamentul medical. Pentru a nu fi pe dinafară, se încarcă cu competențe medicale, pe care le simulează prin intermediul comitetelor de experți sau a consiliilor. În funcție de cât de repede se răspândește vorba conform căreia nici comisiile formate nu duc la îndeplinire cvadratura cercului, trebuie întocmită o supra- sau o subcomisie pentru o perioadă mai lungă sau mai scurtă, pentru a duce de nas în continuare, pe termen scurt, opinia publică.

Chiar și membrii acestor supra- și subcomisii care au fost de multe ori naivi din punct de vedere politic, au fost duși de nas și abuzați. Competența despre care se vorbeșe ocazional este folosită politic numai atunci când este utilă consolidării dreptului la putere. Dacă rezultatele nu se potrivesc, politica le ignoră sub pretextul obișnuit, cusut cu ață albă: transformare „socială, nu echitabilă”, ,politică, nu realizabilă” și așa mai departe.

Mai recent, directivele politice asupra comisiilor „științifice” corespunzătoare par să solicite pe față rezultatul dorit.

Miezul problemei nu se poate rezolva pe plan medical.

\section{Noi coaliții de interese}

Vechile categorii „dreapta - stânga” sunt depășite. În ultimii ani a luat fiinţă o coaliție dezastruoasă a intereselor economice globale și a intereselor pentru putere ale politicienilor.

Vechile conjuncturi de putere formate din partidele de stânga și sindicate și-au pierdut dreptul la reprezentarea exclusivă în politica socială. Lor li s-au alăturat partidele de centru și cele de dreapta, fiind dreptul lor să dorescă să ia parte la procesul de redistribuire. Sindicatele (împreună cu casele de asigurări medicale) au trebuit astfel să își piardă din putere.

S-au alăturat parteneri total noi. Întreprinderi globale au descoperit piața medicală ca și câmp de activitate pentru interesele lor economice; cu circa 4 miliarde de euro pe an și cu o potențială tendință de creștere, această devine accesibilă. Acestea construiesc împreună cu puterile politice complexul medical industrial. Opțiunile, pe care acești „players” le văd, constau într-o „industrializare”, adică într-o standardizare a afacerii medicale. Pe lângă așa-numitele „efecte sinergetice” și „rezerve economice”, trebuie găsite și accesate câmpuri, pentru a realiza profitul necesar. Adevărații „players”, pacient și medic, se transformă, în cadrul acestor raționamente, în pioni pe tabla de șah, care pot fi împinși încolo și încoace și sacrificați, pentru a ajunge la aceste efecte. 
Medicul și pacientul nu au nevoie de un intermediar, până la un asigurator pentru marile riscuri existențiale ale vieții; ei pot interacționa de obicei fără o a treia parte. Bineînțeles că nu apar opțiuni, când persoane din afară câștigă din schimbul între performanță și bani.

Aceasta explică neobișnuita coaliție dintre economia globală și politica socială. Fără conjunctura care implică cele trei părți: pacientul - sistemul de prestare de asigurări - medicul, economia globală nu ar intra în joc. Tocmai datorită sistemului de prestare de asigurări condus de stat, apare posibilitatea de a se realiza câștiguri din acest sector, care nu au nici o legătură cu creșterea în valoare a unei mărfi.

\section{Cine investeşte în socialism?}

Cum stau cu șansele cei care avansează fonduri private? Banii sunt investiți într-un sistem de prestare de asigurări ruinat. Un risc care nu poate fi trecut cu vederea, nu îi poate avantaja pe cei care avansează fondurile, deoarece capitalul privat este la fel de restrâns și sleit datorită prestării de asigurări și a scopurilor bugetului, ca și cel al cabinetelor medicale independente. Dacă efectele sinergetice ale lanțurilor de concerne la început privilegiate de politică au avut de suferit, atunci trebuie să fie tot așa de epuizate ca toate celelalte. Acest lucru este valabil atât pentru spitale, cât și pentru îngrijirea ambulatorie. Așadar, de ce face politica această deviere? Pentru a îngropa cabinetele medicale independente și pentru a câștiga timp.

Deoarece sistemul de prestări de asigurări trebuie să îi exploateze pe toți, ideea de înlocuire a structurii până acum liber-profesioniste, cu lanțuri de concerne anonime, nu a fost un răspuns pentru problema de bază a prestării de asigurări. Lanțul cabinetelor medicale trebuie să standardizeze. Interesul de capital stabilește, nu medicul angajat. Concernele nu-și pot permite procesul de investigare bazat pe medicină. Propria inițiativă a medicilor și nevoile individuale ale pacientului nu au loc. Rămâne o medicină împărțită standardizat.

În spate stă o rațiune politică solidă: cum descoperă un factor de perturbație de prim rang la pacienții majori, politica vede în medicii independenți și în farmaciștii independenți amenințarea activităților sale, deoarece aceștia le pot încă indica pacienților unde greșește politica. Politica nu dorește independență pentru pătura de mijloc; aceasta este un spin dureros în ochi pentru cei de la putere.

\section{Guvernare politică în loc de autonomie}

Calea greșită spre un sistem de sănătate publică cu o economie planificată este indicată de eliminarea completă a autonomiei odată lăudată. În lipsa unor cunoștințe proprii, statul a lăsat la început libertate de acțiune, care a permis o anumită creativitate și libertate de decizie. De la lege la lege, aceast spațiu de acțiune devine tot mai restrâns. Din anul 2006 a existat un flux de acte normative noi. În anul 2009, avocatii au numărat cateva mii de acte normative emise, dar astăzi nu mai numără nimeni ordonanțele, pe care medicii nu trebuie să le divulge victimelor bugetului. Cine le și poate explica?

Inițial, suveranitatea contractelor era impusă de părțile contractante. Apoi a urmat nevoia de împăcare cu tribunalul de arbitri. După aceea, a intervenit statul în evaluarea preformanțelor medicale (CoCa, NoCoCa).

Întocmirea bugetului, restructurarea, colectările interminabile ale datelor, compensarea structurilor de risc ale caselor de asigurări și multe altele, nu pot rezolva nici o problemă pe termen lung, în schimb aduc noi probleme permanente. Statul afirmă că au existat destui bani, dar casa de asigurări trebuia să îi împartă corect, iar medicii sa îi folosească cu chibzuință.

\section{Reglementări anormale}

Criza sistemului a fost programată de politică. Pe măsură ce acest lucru devenea tot mai clar, asociațiile profesionale din sistemul sanitar trebuiau să readucă sistemul la normal, în timp ce acesta era încetul cu încetul demontat de stat. Un exemplu bun este introducerea întocmirii bugetului: medicii trebuie să satisfacă toate nevoile pacienților, în timp ce casele de asigurări au voie să achite numai bugetul stabilit de politică.

Rațiunea politică era clară de la bun început, iar Bismarck a recunoscut-o, urmând apoi să fie doar deghizată. Statul nu vroia să facă munca insalubră, de aceea exista așa-numita autonomie a 
profesiilor medicale. Aceasta era bună pe post de „țap ispășitor” când ceva mergea prost. Așa era întotdeauna, unii trebuiau combătuți, iar guvernul putea ține cont numai de aplauze.

Deci, dacă statul s-ar fi limitat la această situație în care oamenii nu se pot ajuta singuri și dacă nu ar fi avut pretenții la atotputernicie, ar fi fost pe drumul cel bun. Drumul cel bun era subsidiaritatea.

Clasa politică a putut să prevină cu ușurință cursul autonomiei profesiei. Individul nu conta pentru aceștia, lucru ce devine astăzi tot mai evident.

Încă de decenii, cu un serviciu sanitar obișnuit, așa fatal cum ar fi fost acesta, statul însuși ar fi trebuit să preia asumarea răspunderii în cazul reglementărilor anormale ale guvernării sale politice. Autonomiile profesionale ar fi trebuit, de dragul lucrului în sine, să înștiințeze statul despre toate consecințele. Dar statul s-a ferit și se va feri în continuare să fie răspunzător pentru politica sa. Pe de o parte a găsit și lachei bine plătiți (printre medici) în aceste „autonomii”, care ca și el nu erau răspunzători pentru nimic, așadar nu își asumau nici un risc, iar pe de altă parte profesiile medicale, pe care le putea stoarce de bani și apoi învinovăți.

Așa-numitele autonomii medicale și stomatologice ar fi trebuit de mult să dea o replică misiunii primite, aceasta fiind de neîndeplinit, deformată și în dezavantajul pacienților. Ele nu puteau nici pe departe reprezenta nici interesele medicilor, nici indirect pe cele ale bolnavilor. Autonomiile medicale și stomatologice, din moment ce țineau secrete aceste lucruri, deveneau ele însele complici; ele mergeau mai departe, având grijă să prevină „ceva mai rău”.

Clasa politică nu a vrut niciodată o reprezentare cu drepturi egale a intereselor medicilor. De la bun început aceștia s-au luptat în zadar pentru egalitate în arme. Succese sporadice ale autonomiei medicale împotriva caselor de asigurări medicale au dus la reacții din partea legiuitorului, pentru a preveni astfel de situații pe viitor.

Argumentele la subiect și propunerile de concepte ale medicilor și medicilor stomatologi nu sunt luate în considerare; ele rămân retorice atunci când ajung la „masa tratativelor”. Statul discută de ani de zile rezultatul tratativelor, iar în cel mai bun caz a permis un joc cu sumă nulă. Pentru a nu mai fi surprinsă de rezultatele neașteptate ale tratativelor, a fost instalată pas cu pas guvernarea directă și necontrolată.

\section{Politică de reglementare în loc de politică de expansiune}

Aici trebuie să amintim un termen, pe care oamenii de știință îl știu prea bine, dar pe care ceilalți îl ocolesc cu frică, deoarece demască politica actuală: politica de reglementare. A acționa conform politicii de reglementare înseamnă că statul stabilește un cadru corect, pe care apoi îl retrage. Politica de reglementare se îndreaptă spre viitor, și nu spre dominația unei clase. Politica în spiritul reglementării și respectului în fața statului de drept garantează libertatea cetățenilor.

Politica de reglementare din sistemul de sănătate publică trebuie în primul rând să protejeze relația medic-pacient și trebuie totodată să ceară cetățenilor să se ajute singuri întâi de toate. Sistemul românesc de prestare de asigurări cu dreptul la atotputernicie nu poate permite acest lucru. Politicienii care se gândesc mai mult la perioadele lor de alegeri, știu de asemenea acest lucru. Pacientul român al caselor de asigurări nu este liber. El nu este suveran, ci un supus al statului.

Medicii și asociațiile lor liberale trebuie să formuleze cerințele de reglementare politică și nu au voie să se epuizeze în proteste disparate. Ei sunt pe drumul cel bun cu o cerere pentru o relație nealterată medic-pacient. Formula „fezabilității politice” este un argument fictiv al adversarului unei politici de reglementare orientată spre viitor, la care medicii nu au acces.

\section{Politicienii sunt protagoniștii scandalului propriu-zis}

Când politicienii doresc din nou să ia o parte din drepturile cuvenite profesiilor medicale, fac scandal, știind și cum să îl provoace. În aceste cazuri ei sunt de fapt scandalul propriu-zis. Statul însuși, care domină sistemul, ar fi trebuit să își asume riscul cu un sistem clasic de sănătate publică de 
stat. Deoarece el știe că nu poate face acest lucru, îi exploatează tot mai mult pe cei care lucrează pentru el. Statul îi tratează nu ca pe niște susținători legali ai sistemului, ci ca pe o masă de consumatori.

Viitorul asigurărilor medicale obligatorii nu reprezintă pentru politicieni o întrebare privitoare la un lucru, ci una cu privire la dominație. Medicii au competențele necesare tratării pacienților, de accea ar fi trebuit să fie primii critici ai abuzului sistemului. Nimeni altcineva nu va face acest lucru pentru ei.

Înstrăinarea procedeelor medicale prin intermediul politicii reprezintă problema cheie a actualelor asigurări medicale obligatorii. Politica refuză tot mai mult punctul de vedere al moralității. Politica forțează medicii să se lupte pentru supraviețuire, în loc să își facă meseria. Astfel, în timp ce calitatea, adică dăruirea, este taxată sever, etica și motivația dispar. Drept urmare, sistemului medical îi lipsesc persoanele active, de care de fapt depinde. Inevitabil esența sistemului de sănătate publică este distrusă. Pentru a o recondiționa, este nevoie de mai multe generații.

\section{Medicii în secolul XXI}

În ce poate consta o reorientare a medicinei în secolul XXI și în ce nu? Până acum pare lipsită de perspectivă. Pentru Walten Krämer, profesor de statistică economică și socială la universitatea Dortmund, este o "mare minciună medicală [...] refuzul deja bolnăvicios de a privi în ochi dilema centrală a fiecărei politici sanitare moderne, prăpastia tot mai mare dintre fezabilitate si finanțabilitate." Progresul medicinei și evoluția nefavorabilă a populației sunt de nestăvilit.

De neînlocuit este relația directă dintre medic și pacient. Reglementarea acestei relații trebuie să cadă; ea este un fruct al birocrației terapeutice. Hotărârile străine nu pot decât să dăuneze însănătoșirii. Afirmația conform căreia se dorește prevenirea unui „sistem medical format din două clase”, este necinstită și de neîndeplinit. Valoarea sănătății este văzută de fiecare persoană în alt fel.

Oamenii trebuie să înțeleagă și vor înțelege din nou că drepturile la anumite lucruri trebuie să rămână limitate. Bineînțeles că la nevoie trebuie acordat ajutorul, dar în primul rând este solicitat autoajutorul. Numai așa se poate remedia singur sistemul de sănătate publică. Costul acestei acțiuni nu poate fi stabilit de birocrați. Oamenii trebuie să poată să hotărască pentru ei înșişi ce valoare are sănătatea lor.

Medicina nu poate fi reglementată. Termenul de îngrijire „necesară” este o ficțiune birocratică, care trebuie acceptată ca motivație pentru existența aparatelor administrative. Numai medicul și pacientul pot hotărâ ce este necesar. Istoria medicinei este ca și evoluția omenirii, o inovație permanentă, niciodată finalizată. Un sistem de constrângere administrat central care distruge capacitatea de a fi activ din punct de vedere medical, dar și libertatea terapiei, este incapabil să evolueze în continuare. Inovația nu poate veni din birouri. Acestea pot numai reglementa, respectiv paraliza sistemul.

$\mathrm{Nu}$ există decât o singură cale: demascarea puterii însăși, a abuzurilor ei și numirea consecințelor pe care le va avea de suportat sistemul de sănătate publică. Este timpul potrivit pentru acestea, iar ușa este deschisă. Publicul a remarcat incapacitatea sistemelor politice de a găsi soluții. Fie medicii învață oamenii politici să reacționeze, fie tot ce spun purtătorii de cuvânt ai medicilor este inutil.

\section{Postfață}

Aceast material nu constituie opinia instituțională a Colegiului Medicilor din România, cel puțin nu deocamdată, și nici a unei alte organizații din interiorul sistemului de sănătate sau din afara lui.

El este rezultatul observării funcționării sistemului atât în România, cât și în Germania -țara de origine a asigurărilor sociale obligatorii. El nu dorește să convingă pe nimeni de vreun adevăr, doreste doar să facă o invitație la a privi și din alt punct de vedere o realitate cotidiană. El este o bază de discuții și nu de polemici, este o invitație la analiză.

Chiar dacă pe alocuri tonul și cuvintele par îndeajuns de dure, ele nu se referă la persoane sau partide politice anume, ci la „politic” în general, văzut între prerogativele și constrângerile sale. Vă rog să constatați și pe această cale că etica profesională este aceea care dă valoare perenă profesiei, alături de cunoașterea medicală, iar nu reglementările temporare. 
EVALUAREA GRATIFICAȚIEI PACIENȚILOR RELATIV LA CALITATEA SERVICIILOR MEDICALE ŞI IDENTIFICAREA VALENȚELOR POZITIVE ŞI NEGATIVE ALE RELAȚIEI ẢCESTORA CU MEDICII

\section{Cât de mulțumit(ă) sunteți de următoarele aspecte ale funcționării Sistemului de Sănătate în județul dvs.?}

STAREA FIZICĂ ŞI IGIENICA A CLĂDIRILOR DIN SERVICIILE PROFESIONALISMUL / PREGĂTIREA ALTOR CATEGORII PUBLICE DE SẲNĂTATE (DE STAT) - SPITALE, CLINICI, DE PERSONAL MEDICAL DIN SPITALE ŞI CLINICI SANATORII, ETC

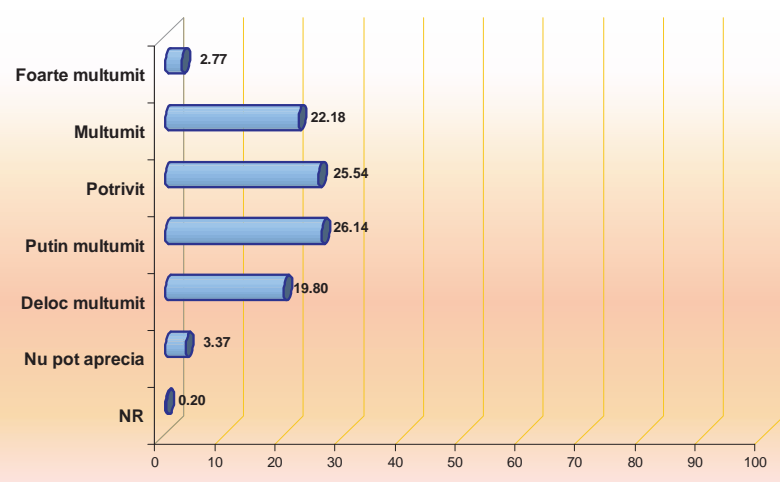

DOTAREA CU MIJLOACE DE INTERVENȚIE ÎN CAZ DE URGENTĂ - AMBULANȚE, PERSONAL CALIFICAT, INSTRUMENTAR MEDICAL ADECVAT

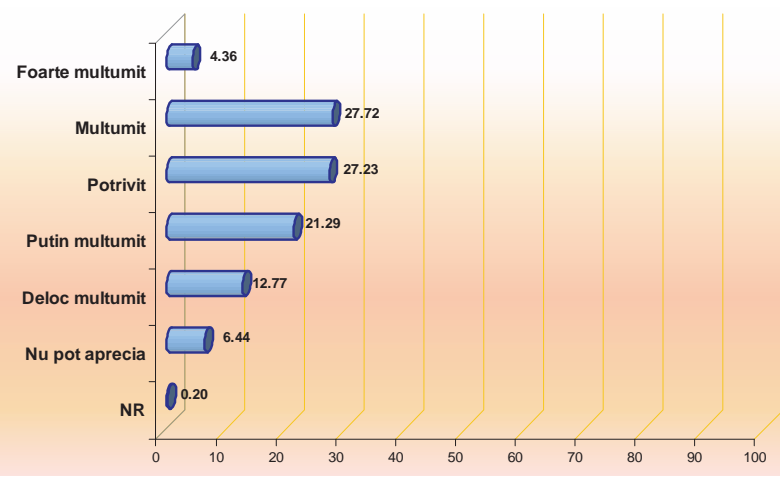

PROFESIONALISMUL / PREGĂTIREA MEDICILOR DIN SPITALE ŞI CLINICI

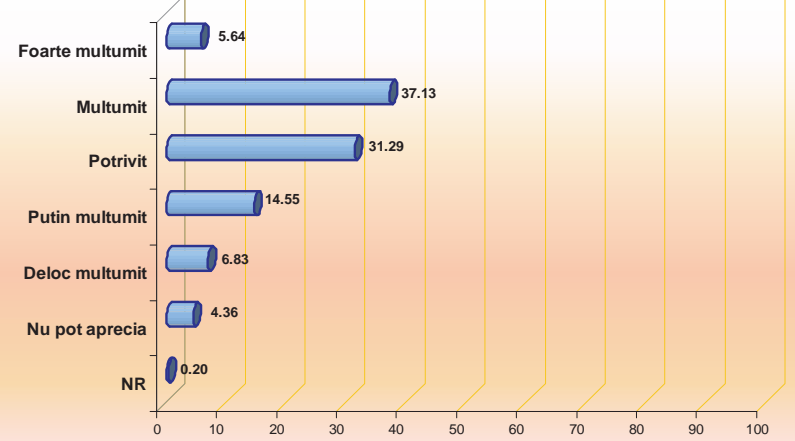



CAPACITATEA DE COMUNICARE A MEDICILOR CU PACIENTIII (POLITETEA, TRANSMITEREA INFORMATIILOR MEDICALE, ALTE MESAJE UMANE ŞI PROFESIONALE)

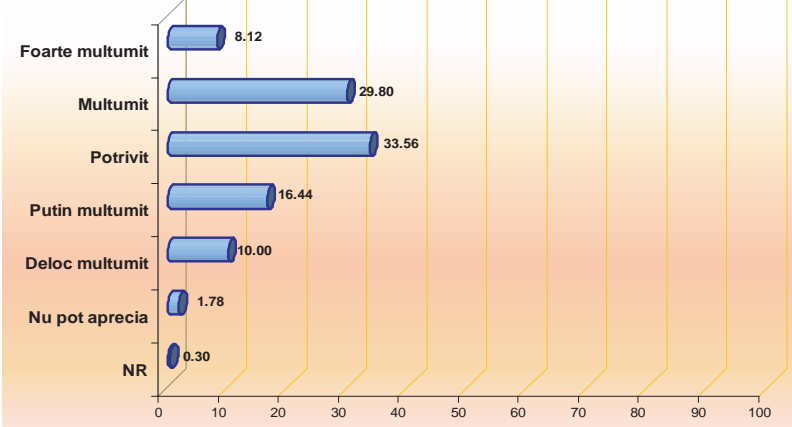

CAPACITATEA DE LUCRU A UNITĂTILOR SANITARE (NUMĂR DE PATURI, NUMĂR DE PERSONAL ANGAJAT, DOTAREA CU ECHIPAMENTE ŞI MEDICAMENTE)




Cât de mulțumit(ă) sunteți de următoarele aspecte ale funcționării Sistemului de Sănătate în județul dvs.?

NUMĂRUL ŞI DIVERSITATEA CLINICILOR ŞI SERVICIILOR MEDICALE DE SPECIALITATE

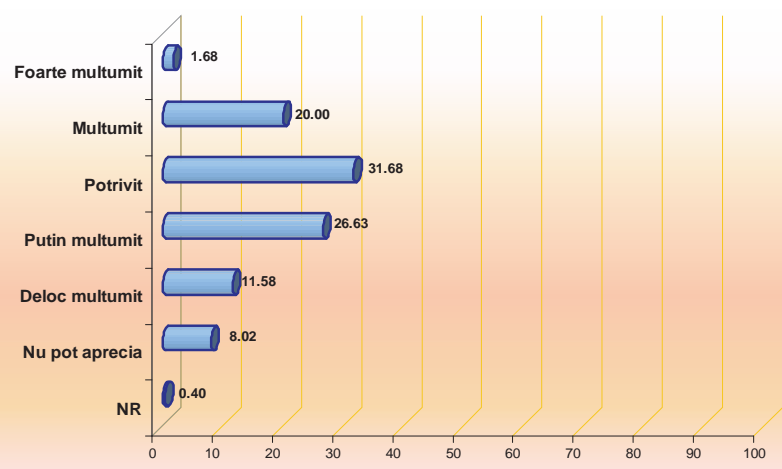

DOTAREA TEHNICO-MEDICALĂ A UNITĂȚILOR SANITARE



PROGRAMELE DE PREVENIRE ŞI COMBATERE A BOLILOR EPIDEMICE (GRIPE, MENINGITE S.A.)

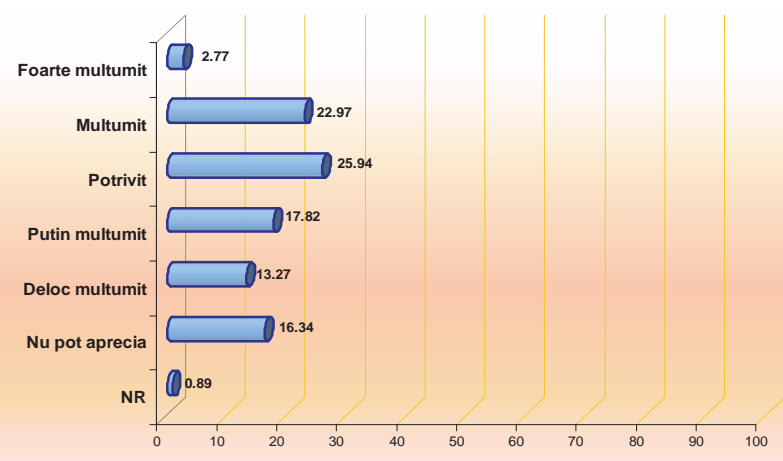

În ce măsura considerați că vă este respectat dreptul la servicii medicale asigurate de către Casa Județeană de Asigurări de Sănătate?



La modul general, din punctul de vedere al calității, dintre serviciile medicale de stat şi cele particulare (private), pe care le puneți pe primul loc (le preferați)?

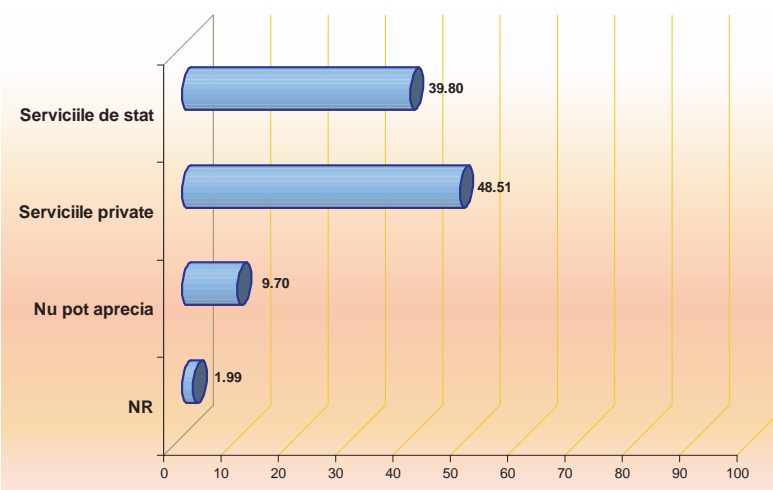


Apeciați cu note de la 0 la $10(0=$ deloc, $10=$ maxim) măsura în care Statul Român asigură Sistemului de Sănătate următoarele condiții:

NIVEL DECENT DE SALARIZARE A MEDICILOR

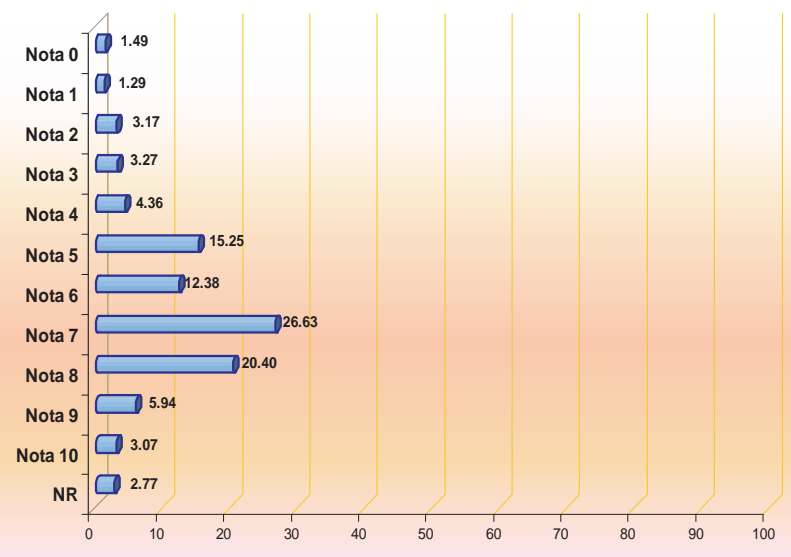

CONDIȚII DE LUCRU PEROFESIONALE PENTRU MEDICI

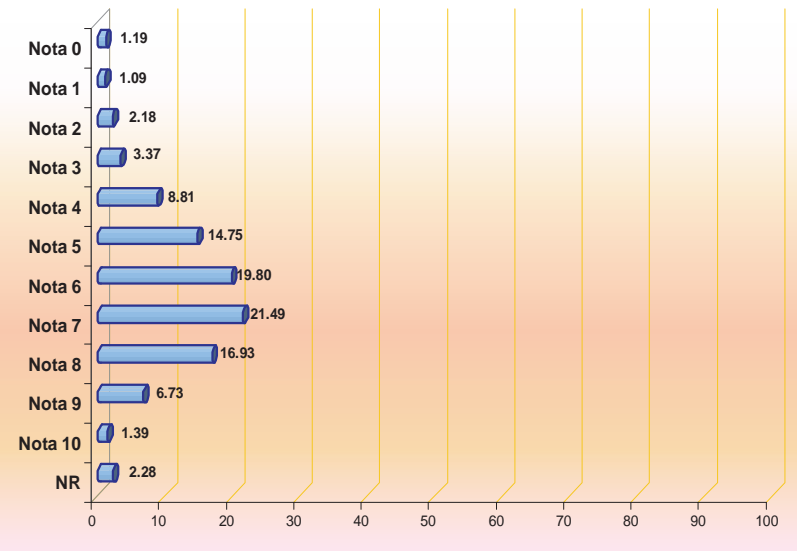

ELIBERAREA LA TIMP DE PE REȚETE COMPENSATE ŞI GRATUITE A MEDICAMENTELOR ACORDATE PACIENȚILOR



DOTARE TEHNICĂ MODERNĂ ÎN SPITALE ŞI CLINICI




În general, cât de multă încredere aveți în:

MEDICUL DE FAMILIE

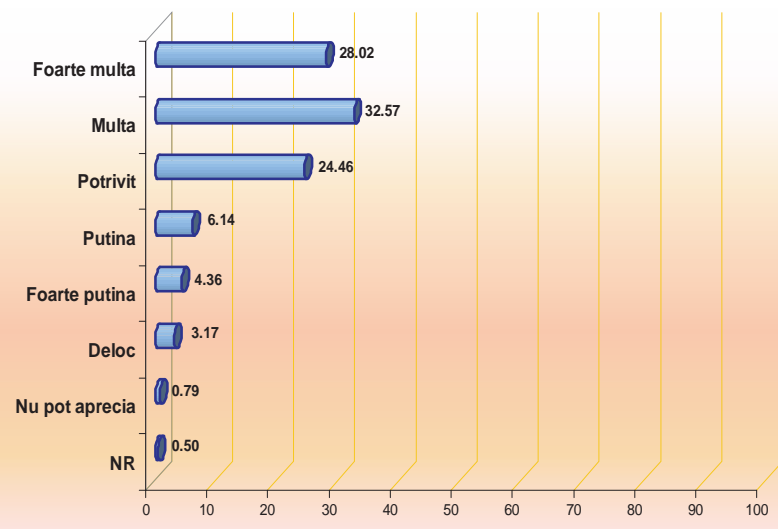

MEDICII DIN UNITĂȚILE PRIVATE

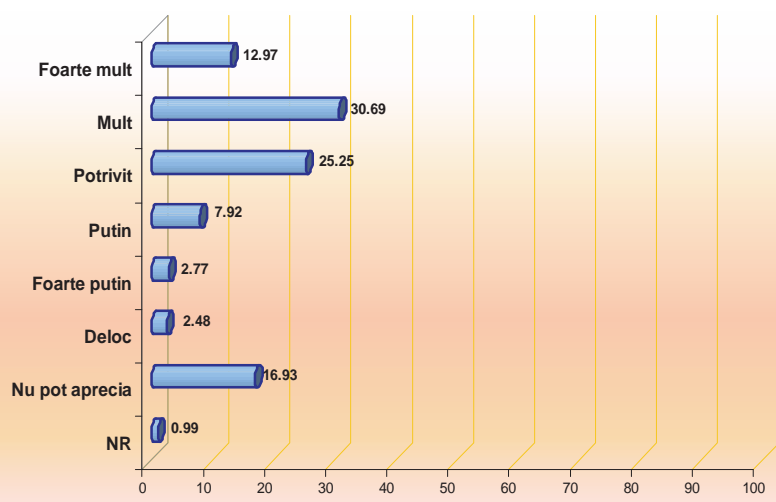

\section{Care credeți că sunt cele mai mari 3} atuuri / avantaje pe care le are județul dvs. cu privire la Sistemul de Sănătate, în comparație cu restul țării?



MEDICII DIN UNITĂȚILE SANITARE DE STAT

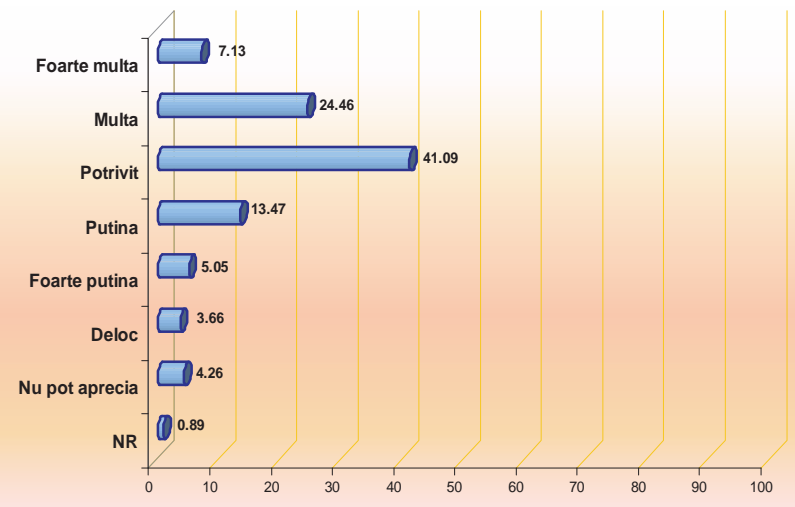

CELELALTE CATEGORII DE PERSONAL MEDICAL DIN UNITĂȚILE PRIVATE

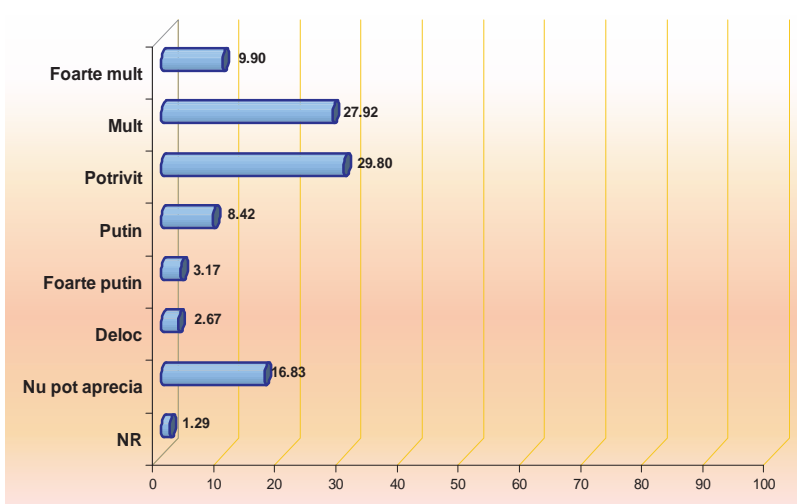

Care credeți că sunt cele mai mari 3 carențe / dezavantaje pe care le are județul dvs. cu privire la Sistemul de Sănătate, în comparație cu restul țării?

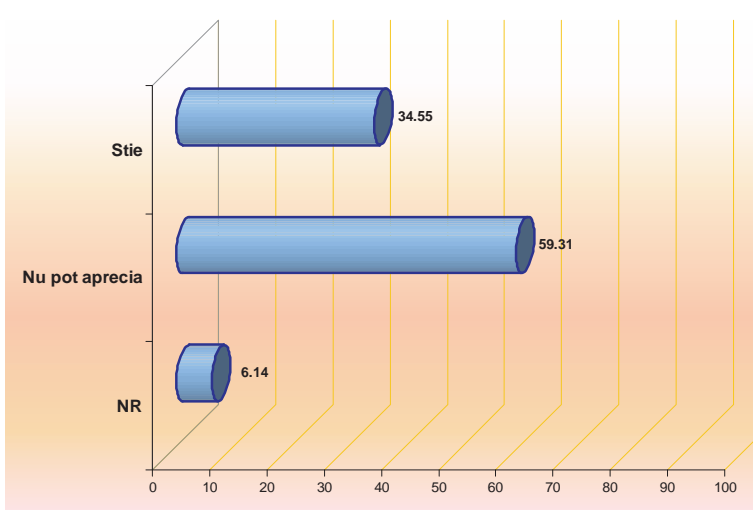


Cu aproximație, cât de des ați apelat în ultimii 2 ani la serviciile medicale ale următorilor specialişti?

MEDIC DE FAMILIE



MEDICI DIN CABINETE DE SPECIALITATE ŞI / SAU POLICLINICI DE STAT

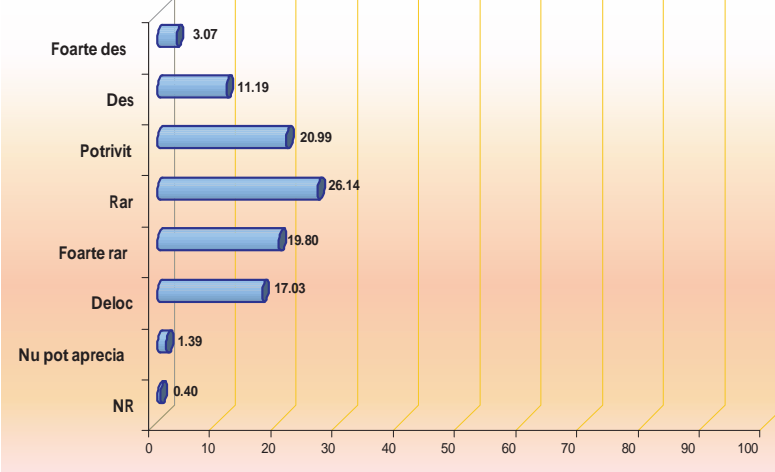

MEDICI DIN SPITALE

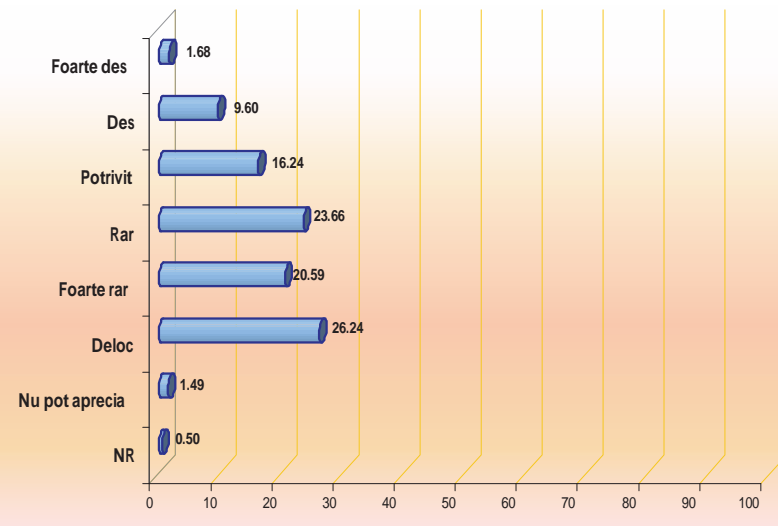

MEDICI DIN LABORATOARE MEDICALE

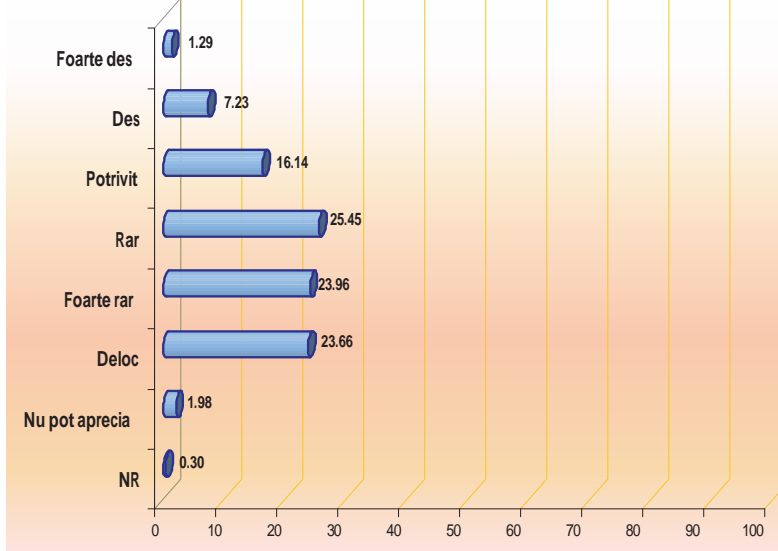

MEDICI DIN CABINETE SAU CLINICI PARTICULARE

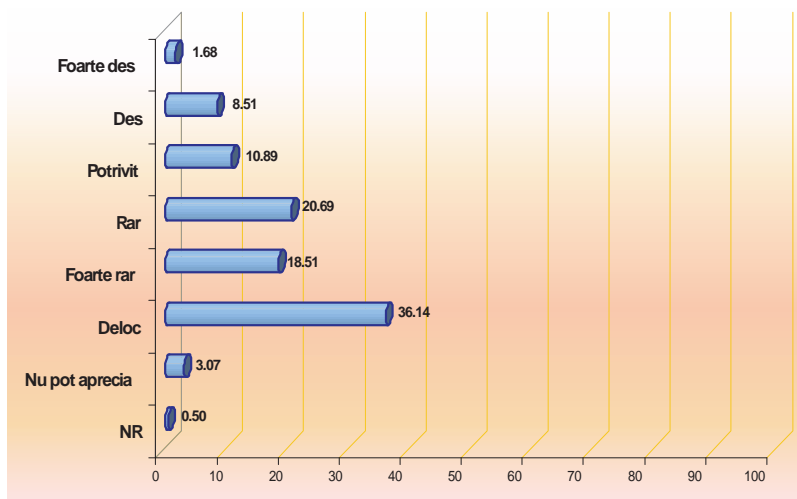

Care este, cu aproximație, venitul dvs. personal într-o lună de zile, indiferent de sursele din care se realizează acesta?

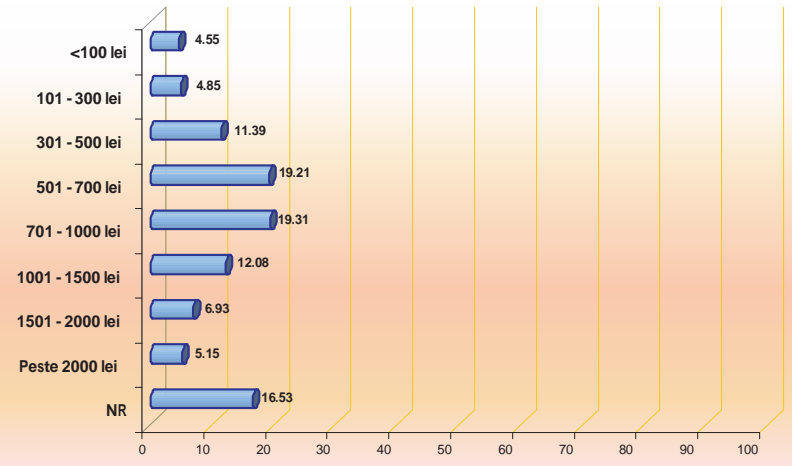


Pe care dintre următoarele afirmații le considerați adevărate şi pe care false?

PACIENTUL DE RÂND (OBIŞNUIT) ESTE TRATAT ACELAŞI MEDIC ESTE MAI ATENT CU PACIENȚII LA NECORESPUNZĂTOR DE CĂTRE PERSONALUL MEDICAL CABINETUL PARTICULAR DECÂT LA SPITAL DIN ȚARĂ

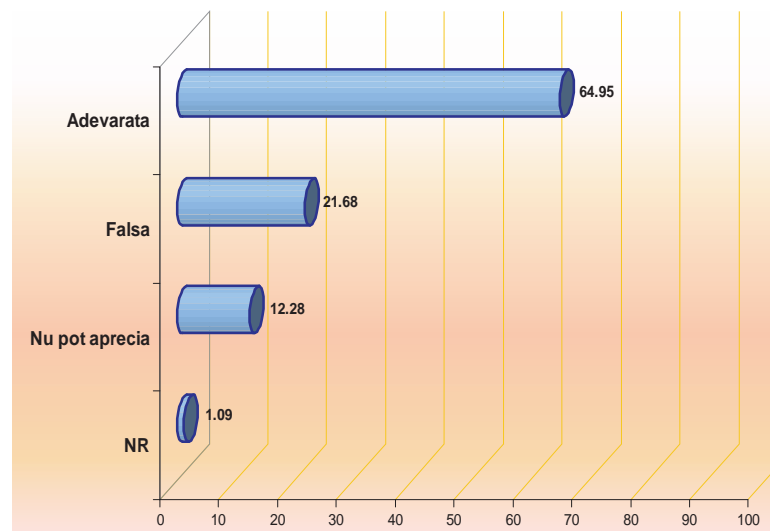

ÎN ULTIMII 5 ANI, SISTEMUL SANITAR DIN ROMÂNIA S-A SISTEMULSANITAR ÎN MEDIUL RURALESTESUBDEZVOLTAT ÎMBUNĂTĂȚIT

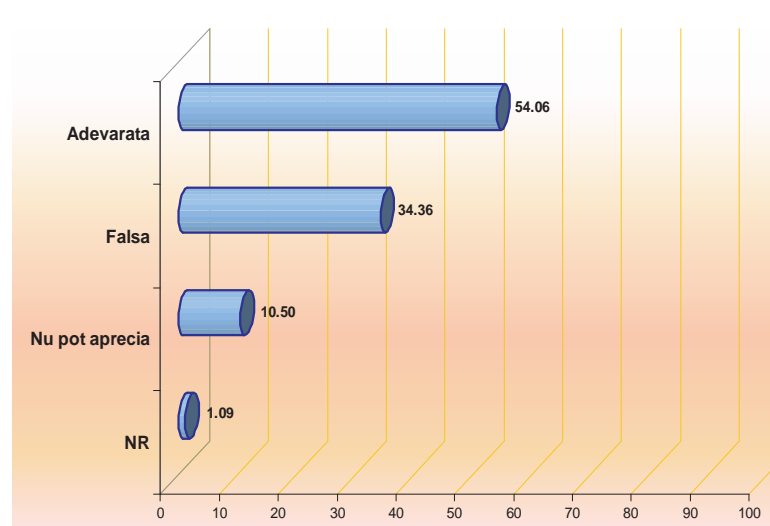

PENTRU OPERAȚII DIFICILE ŞI ALTE TRATAMENTE MAI SPECIALE, ROMÂNII TREBUIE SĂ MEARGĂ ÎN STRĂINĂTATE

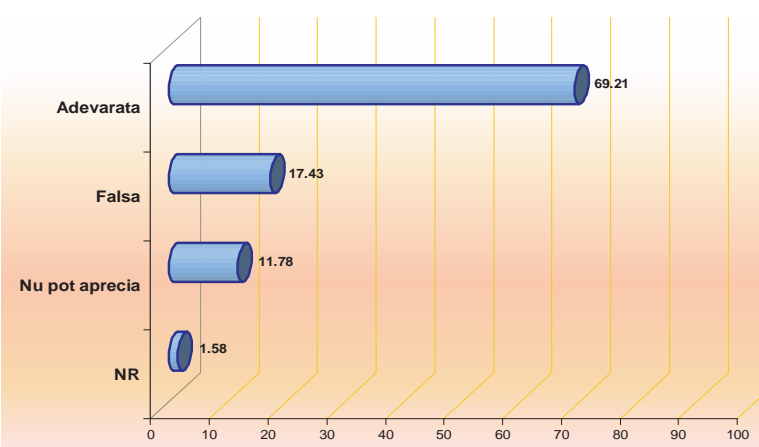





MEDICII EMIGREAZĂ DIN CAZUZA NIVELULUI SCĂZUT DE TRAI (SALARII ŞI CONDIȚII SOCIALE REDUSE)




ESTE NECESARĂ PUNEREA LA PUNCT A UNUI SISTEM PRIVATIZAT DE ASIGURĂRI DE SĂNĂTATE, DUPA MODELUL PENSIILOR PRIVATE



Printr-o apreciere de ansamblu, acordați o notă de la 1 la 10 funcționării actuale a sistemului sanitar în România ( 1 = foarte proastă, 10 = foarte bună)

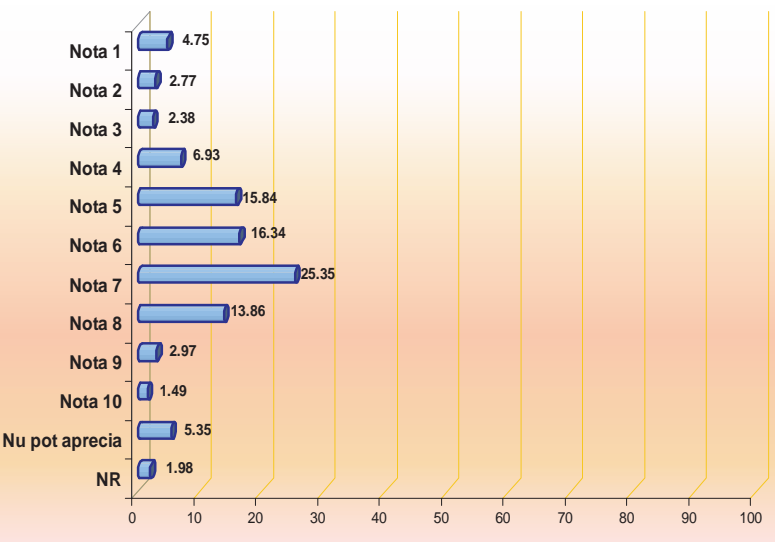

Indiferent dacă apreciați că este bună sau rea, spuneți cine credeți că este responsabil pentru starea serviciilor medicale din România?

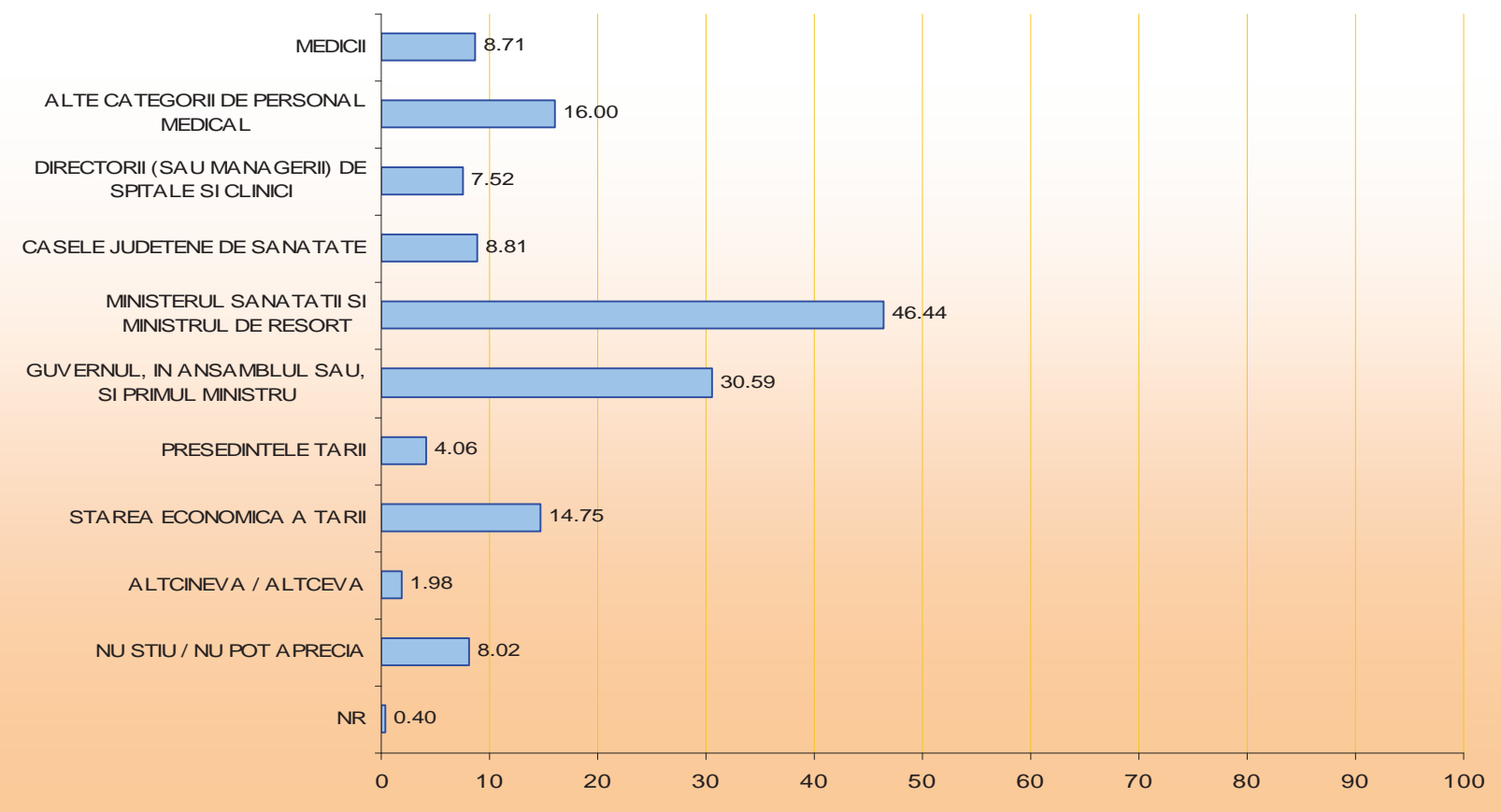


APARTENENȚA LA GEN

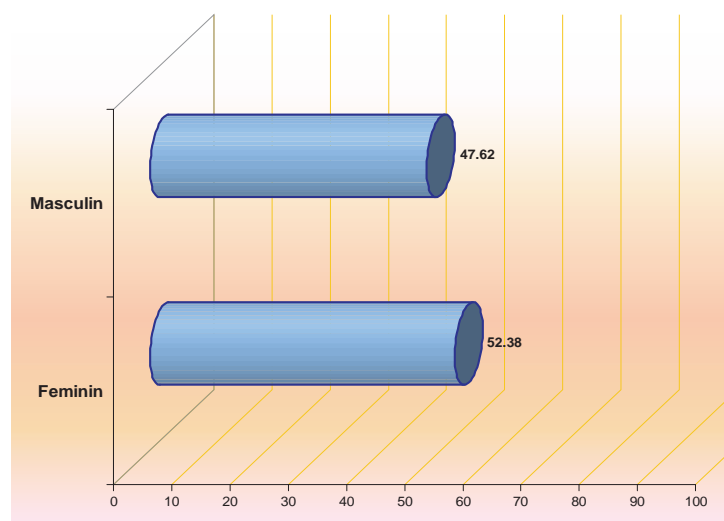

VÂRSTA PE INTERVALE

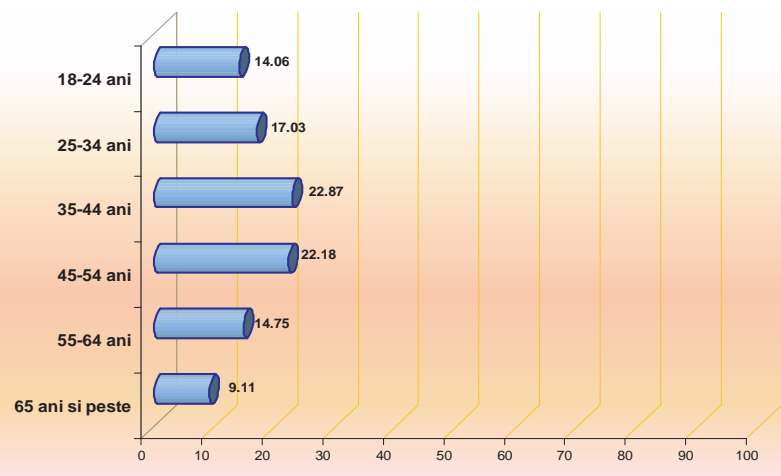

\section{OCUPAȚIE}

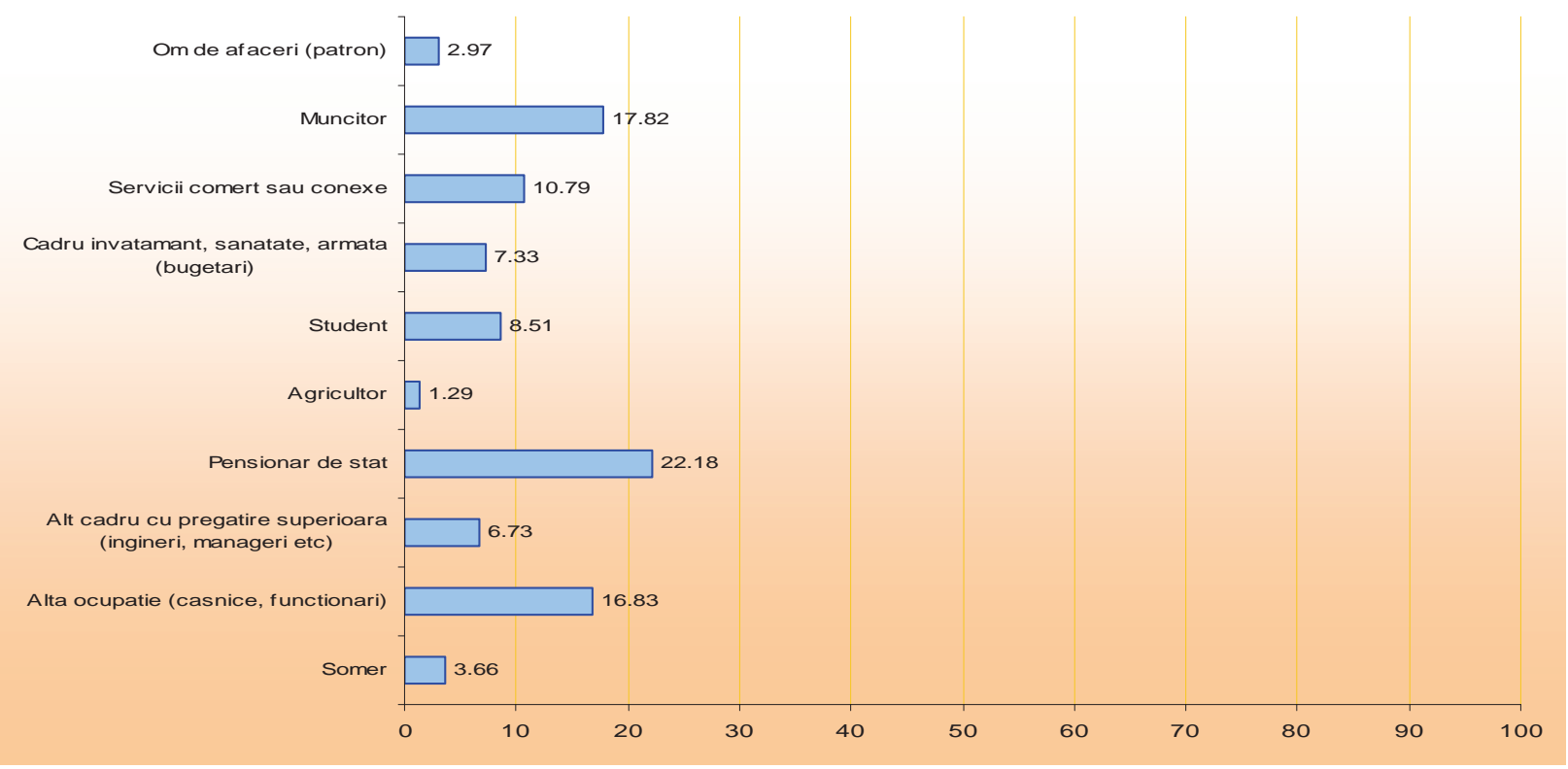

DVS. PERSONAL SAU FAMILIA DIN CARE FACETI PARTE (ŞI CU CARE LOCUIȚI) AVEȚI AUTOTURISM PROPRIETATE PERSONALĂ:



STRUCTURA EŞANTIONULUI PE REGIUNI ISTORICE






\section{Locuința dvs. are:}

APĂ POTABILĂ DE LA REȚEAUA ORAŞULUI

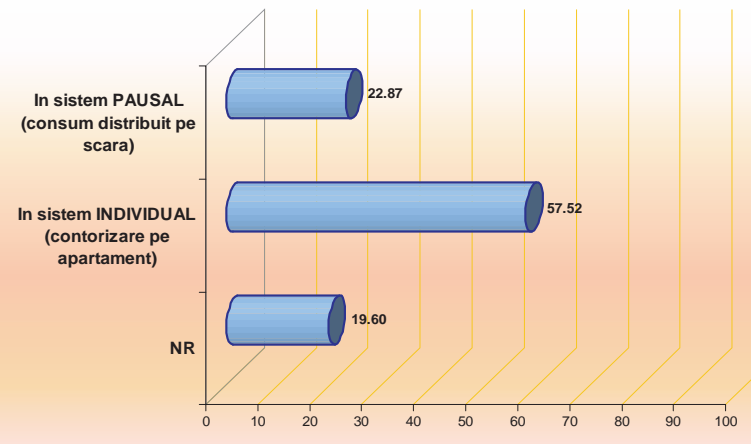

CANALIZARE

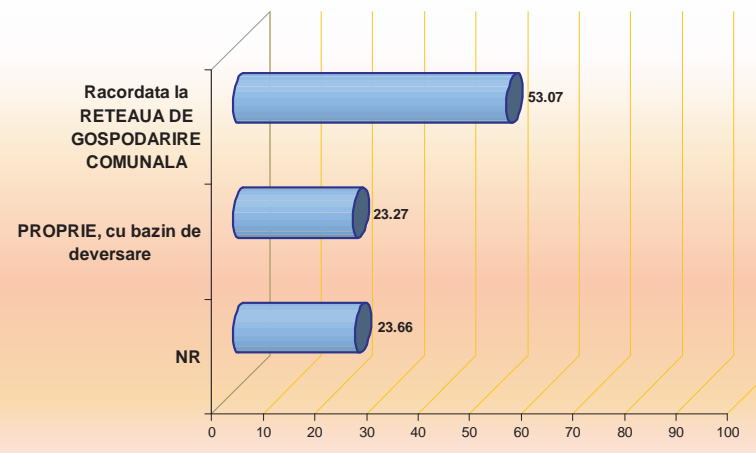

\section{CENTRALĂ TERMICĂ PROPRIE}



APĂ MENAJERĂ CALDĂ CURENTĂ DE LA REȚEAUA ORAŞULUI

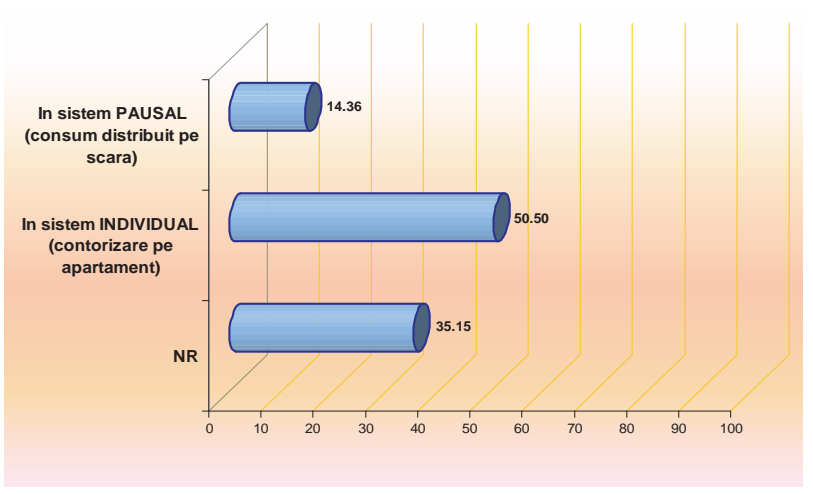

GAZ

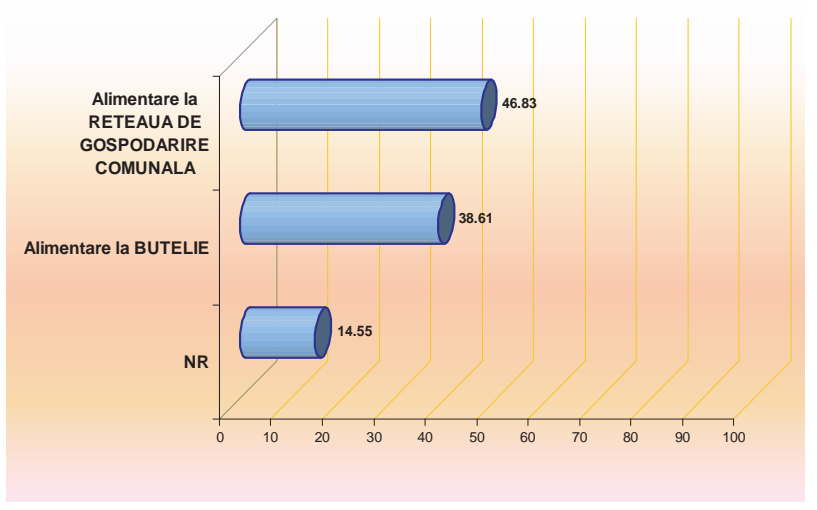

\section{Şcolaritate}

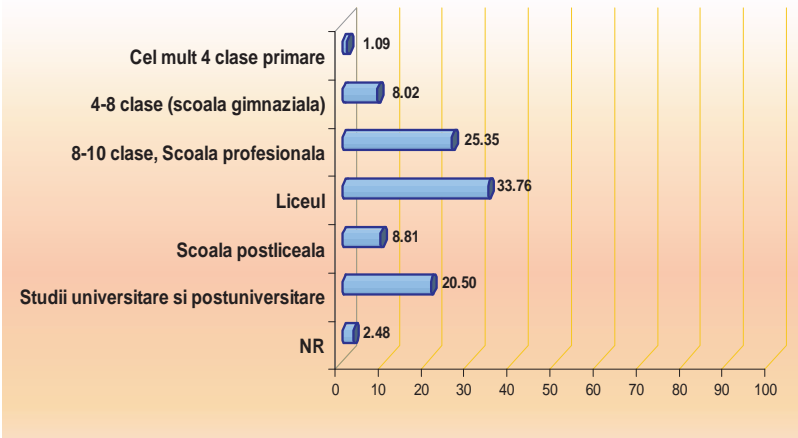

